\title{
As dimensões do conhecimento agroecológico: a experiência dos agricultores familiares assentados em Viamão, $R S$
}

\author{
Potira V. Preiss \\ Universidade de Santa Cruz do Sul - Santa Cruz do Sul - RS - Brasil \\ ORCID: https://orcid.org/0000-0002-0098-1588
}

\begin{abstract}
Resumo
A agroecologia tem sido debatida em nível internacional como uma referência para a construção de sistemas alimentares mais sustentáveis, se tornando o foco de centros de pesquisa e agências de desenvolvimento. No entanto, é importante considerar que a transição agroecológica passa necessariamente por um processo de construção de conhecimentos por parte dos atores sociais que a protagonizam. Este artigo tem como objetivo apresentar e discutir as dimensões do conhecimento agroecológico vivenciado pelos agricultores familiares vinculados ao Assentamento Filhos de Sepé em Viamão, RS. Os dados são fruto de uma pesquisa qualitativa e tem como referencial teórico-analítico abordagens relacionais do conhecimento que compreendem este como o resultado de um processo integral e dinâmico da interação dos seres no mundo. Através de observação participante, entrevistas e construção colaborativa de ilustrações pode-se identificar três dimensões pelas quais o conhecimento agroecológico dos agricultores tem sido construído: a lavoura, o corre e o habitar. Essas dimensões se interpõem e entrelaçam no cotidiano vivido pelos assentados, criando uma série de interfaces e contribuindo para que possam realizar suas atividades produtivas e reprodutivas. Os resultados demonstram um processo de conhecimento complexo, multidisciplinar e heterogêneo que emerge a partir de experiência prática de engajamento dos agricultores com o mundo, rompendo com dicotomias clássicas sobre a relação sociedade-natureza e a agricultura receituária. $\mathrm{O}$ contexto agrícola atual requer agricultores familiares multifacetados, em que as habilidades de manejo de cultivos são apenas uma entre as funções desempenhadas, fazendo com que diferentes aprendizados precisem ser desenvolvidos. A troca de saberes é altamente relevante, seja entre seus pares, técnicos, pesquisadores ou ainda os não humanos com quem interagem cotidianamente.
\end{abstract}

Palavras-chave: Construção de conhecimento. Agroecologia. Reforma agrária. Agricultura familiar. 


\section{The dimensions of the agroecological knowledge: the experience of family farmers settled in Viamão, RS}

\section{Abstract}

Agroecology has been debated internationally as a reference for building more sustainable food systems, becoming the focus of research centers and development agencies. However, it is important to consider that the agroecological transition requires a process of knowledge construction by the social actors involve with it. This article aims to present and discuss the dimensions of agroecological knowledge experienced by family farmers living at Filhos de Sepé Settlement at Viamão, Rio Grande do Sul State. The data are the result of a qualitative research and have a relational approach to knowledge as it's analytical framework, understanding knowledge as the result of an integral and dynamic process of the interaction of beings in the world. Through participant observation, interviews and the collaborative construction of illustrations, we were able to identify three dimensions by which farmers build their agroecological knowledge: lavoura, corre and habitar. These dimensions interpose and intertwine in the daily lives of the farmers, creating a series of interfaces and contributing to their productive and reproductive activities. The results demonstrate a complex, multidisciplinary and heterogeneous knowledge process that emerges from the practical experience of farmer's engagement within the world, breaking with classic dichotomies around nature-society and prescriptive agriculture. The current agricultural context requires multifaceted family farmers, where crop management skills are only one of the functions performed, provoking the need for different learning to be developed. The exchange of knowledge is highly relevant, whether among peers, technicians, researchers or even non-humans with whom they interact daily.

Keywords: Knowledge construction. Agroecology. Land reform. Family farmers

\section{Las dimensiones del conocimiento agroecológico: la experiencia de los agricultores familiares asentados en Viamão, RS}

\section{Resumen}

La agroecología ha sido debatida internacionalmente como referencia para construir sistemas alimentarios más sostenibles, convirtiéndose en el foco de los centros de investigación y agencias de desarrollo. Sin embargo, es importante considerar que la transición agroecológica necesariamente pasa por un proceso de construcción de conocimiento por parte de los actores sociales que la protagonizan. Este artículo tiene como objetivo presentar y discutir las dimensiones del conocimiento agroecológico experimentado por los agricultores familiares vinculados al asentamiento Filhos de Sepé en Viamão, RS. Los datos son el resultado de una investigación cualitativa y tienen como marco teórico-analítico enfoques relacionales del conocimiento, que lo entienden como el resultado de un proceso integral y dinámico de la interacción de los seres en el mundo. A través de la observación participante, entrevistas y la construcción colaborativa de ilustraciones, pudimos identificar tres dimensiones mediante las cuales se ha construido el conocimiento agroecológico de los agricultores: labora, corre y habitar. Estas dimensiones se interponen y entrelazan en la vida cotidiana de los campesinos, creando una serie de interfaces y contribuyendo para sus actividades productivas y reproductivas. Los resultados demuestran un proceso de conocimiento complejo, multidisciplinario y heterogéneo que surge de la experiencia práctica de enlace de los agricultores con el mundo, rompiendo con las dicotomías clásicas sobre la relación sociedad-naturaleza y la agricultura prescriptiva. El contexto agrícola actual requiere agricultores familiares multifacéticos, donde las habilidades de manejo de cultivos son solo una de las funciones que se realizan, por lo que es necesario desarrollar diferentes aprendizajes. El intercambio de conocimiento es muy relevante, sea entre pares, técnicos, investigadores o incluso no humanos con quienes interactúan a diario. 
Palabras clave: Construcción de conocimiento. Agroecología. Reforma agraria. Agricultura familiar.

\section{Introdução}

A agroecologia tem sido debatida em nível internacional como uma referência para a construção de sistemas alimentares mais sustentáveis, se tornando o foco de centros de pesquisa e agências de desenvolvimento preocupadas em equacionar a produção de alimentos de qualidade, com inclusão social e mitigação das mudanças climáticas. (CARRON et al., 2018; IPES-Food, 2016). Conforme o HLPE (2019), a agroecologia se difere de outras abordagens para sistemas agroalimentares sustentáveis porque tem como base processos territoriais construídos por atores locais, que desenvolvem soluções e inovações a partir da cocriação de conhecimentos entre a academia e o conhecimento prático e local dos produtores.

É nesse sentido, que a ampliação da agroecologia se torna complexa, pois diferente do sistema agrícola convencional que possui uma lógica bastante reducionista que permite uma reprodução em alta escala de forma mecanizada e receituária, a expansão da agroecologia passa necessariamente por fomentar o desenvolvimento local de conhecimentos. É nesse sentido que se fala em transição agroecológica, como um processo que acontece ao longo do tempo a medida que os atores locais e comunidades se envolvem com as distintas formas de fazer e pensar agroecologia. Conforme argumenta Canuto (2008), a construção do conhecimento é um pilar do processo de transição, já que é através dela que processos participativos e procedimentos científicos se integram as dinâmicas sociais e econômicas, criando através de experiências uma sólida base para transformações políticas.

Portanto, a construção e a gestão do conhecimento agroecológico torna-se um tema essencial, pois é um resultado dos processos de vivência e experiência dos agricultores na gestão (muitas vezes coletiva) dos bens comuns e nos caminhos encontrados para produção de alimentos aliada ao desenvolvimento sustentável. De forma a contribuir com este debate, o presente artigo tem como objetivo apresentar e discutir as dimensões do conhecimento agroecológico vivenciado pelos agricultores familiares do Assentamento Filhos de Sepé em Viamão, RS. O processo de transição agroecologia deste Assentamento tem uma trajetória bastante peculiar em que as famílias foram obrigadas pelo Estado a se envolveram com a produção agroecológica de forma a não impactar áreas de interesse ambiental localizadas em seu território, o Refúgio da Vida Silvestre Banhado dos Pachecos e a Barragem Águas Claras. Atualmente, o Assentamento Filhos de Sepé faz parte de um complexo produtivo com outros assentamentos da região, levando o Movimento dos Trabalhadores Sem Terra (MST) a ser considerado o maior produtor de arroz orgânico da América Latina.

A pesquisa aqui apresentada tem um caráter qualitativo e uma abordagem etnográfica, que buscou ao máximo conhecer e dar voz direta aos agricultores protagonistas do processo. Tendo como período de análise a safra 2011/2012 em que 90 famílias estiveram envolvidas com a produção do arroz no Assentamento Filhos 
de Sepé, a pesquisa acompanhou 9 agricultores (1 representante de cada grupo de produção) ao longo de uma safra buscando registrar e compreender de que forma o processo de construção do conhecimento agroecológico se expressava e desenvolvia. Além de uma intensa revisão de documentos, a pesquisa envolveu coleta dos dados primários através de entrevistas semiestruturadas, observação participante de práticas de manejo, reuniões, seminários, avaliações de safra, entre outros momentos de relevância ao cotidiano dos agricultores. Envolveu ainda um processo de elaboração coletiva de ilustrações como ferramenta de debate e sistematização de conhecimentos.

Desde o início desta pesquisa, perceber-se que, como de praxe, o conhecimento agroecológico dos agricultores familiares aqui analisados era fruto de múltiplos fatores que envolviam desde suas trajetórias pessoais de vida, de relação com a terra e com a agricultura, de envolvimento com o movimento de reforma agrária e a chegada em um novo território de vida e trabalho. Para acessar esse conhecimento, buscou-se resgatar essas trajetórias, mas também compreender como este se expressava de forma prática no cotidiano dos agricultores. Tendo em vista que a rotina das famílias é bastante influenciada pela atividade agrícola, neste caso, a produção de arroz irrigado, o decorrer do ano acompanha as diferentes etapas e dinâmicas que envolvem o cultivo. Assim, seguindo a perspectiva apresentada pelos atores, identificou-se três dimensões em que o conhecimento agroecológico tem sido construído: a lavoura, o corre e o habitar.

Além desta introdução, o artigo é composto por quatro sessões. Primeiro, apresenta-se uma breve revisão de perspectivas que versam sobre o processo de construção do conhecimento e de como estas se aproximam da agroecologia. $\mathrm{Na}$ sequência, discute-se sobre a trajetória de formação do Assentamento e os principais acontecimentos que interferem nas suas práticas de gestão dos recursos e produção agrícola, entendendo que o conhecimento gerado não pode ser desvinculado desta história ou deste ambiente que passa a ser o mundo de vida das famílias assentadas. A seguir as dimensões do conhecimento são apresentadas, tendo uma subsessão dedicada a apresentar e discutir os conhecimentos expressos em cada uma delas. Ao longo do texto, optou-se por dar voz direta aos agricultores reproduzindo algumas de suas falas de forma a exemplificar sua percepção e saber. Os nomes utilizados são fictícios de forma a proteger a identidade dos agricultores. A última sessão apresenta considerações finais.

Acredita-se que o artigo traz três contribuições em especial ao processo de transição e construção do conhecimento agroecológico. Em primeiro lugar, apresenta um referencial teórico sobre a construção do conhecimento a partir de uma perspectiva relacional da realidade, que tem o potencial de contribuir com os estudos sobre o conhecimento agroecológico. Em segundo, a metodologia de pesquisa com o uso de construção coletiva de ilustrações pode auxiliar a inspirar outros estudos que visam sistematizar conhecimentos desenvolvidos a partir da pratica e vivência dos agricultores. Por fim, a trajetória e os dilemas enfrentados pelos agricultores assentados em Viamão nas três dimensões trazem elementos relevantes para se pensar a relação do Estado frente a reforma agrária, a transição agroecológica e a gestão de áreas de interesse ambiental em conjunto com populações locais. 


\section{Conhecimento, agroecologia e a sistematização de saberes}

Uma diversidade de autores tem se dedicado a compreender como o conhecimento é construído. Este artigo esta embasado em uma abordagem relacional da realidade, que entende que nossos corpos são a fonte primária de envolvimento sensorial com o mundo, portanto os processos de construção de conhecimento se dão a partir da inserção e interação do "ser-no-mundo". Contribuem para esta perspectiva autores clássicos como Heidegger e MerleauPonty, filósofos fenomenologistas franceses que tiveram um papel fundamental ao desenvolverem uma perspectiva ontológica e que o pensamento acontece como uma reflexão sobre o mundo e as "coisas" que nos cercam. Portanto, estabelecem uma oposição crítica ao pensamento cartesiano, em que o conhecimento é considerado uma propriedade da mente, fazendo do corpo um mero objeto conhecido.

Heidegger (2000) argumenta que a prática vem antes da teoria, compreendendo que o que somos como seres humanos, não pode ser isolado da complexa rede de práticas sociais que fazem do nosso mundo cotidiano. Assim, entende-se que o mundo que nos cerca faz parte de quem somos. De forma complementar, Merleau-Ponty defende que nossas percepções não acontecem de maneira linear em uma dinâmica de simples estímulo-resposta, mas através de um desdobramento de reações acerca do que nos rodeia (NÓBREGA, 2008). Temos assim um conhecimento que não é explícito, consciente, mentalmente representativo ou articulado, como propõe Merleau-Ponty (1999) é um conhecimento produzido pela familiaridade. Assim, a medida que certos elementos passam a compor nosso mundo, é a familiaridade que construímos a partir de nossa interação com eles que se torna conhecimento.

Polanyi (1966) fala sobre a dimensão tácita presente em todo saber, esta se refere aos conhecimentos que se tem, mas que encontra dificuldade de ser explicado ou transferido para os outros de forma escrita, verbalizada, codificada. Aprende-se a andar de bicicleta, a tocar um instrumento, sabe-se como fazer porque nosso corpo aprendeu a coordenar um conjunto de movimentos e comandos de forma simultânea. Ensinar alguém a fazer o mesmo passa pela experiência prática e corporal do outro realizar o mesmo engajamento, sendo um conhecimento racional e teórico útil, no entanto insuficiente para que as ações sejam efetivadas.

Não se está aqui negando o papel da mente como construtora do conhecimento, mas sim argumentado uma integralidade entre corpo e mente. Esta perspectiva também é desenvolvida por Ingold (2000) que defende o corpo não como objeto ou ferramenta da percepção, mas sim sujeito da percepção em um contexto em que a mente não é limitada à pele, mas compõe um organismo que interage de forma integral com seu ambiente 1 . É neste contexto que o autor propõe que o conhecimento depende fundamentalmente da imersão e engajamento dos sujeitos em seus mundos, pois mais do que um conjunto de informações recebidas,

\footnotetext{
1 O autor utiliza a noção de "ambiente" como um resultado emergente da relação entre o ser e o mundo, refutando a noção de "natureza" que segue uma prerrogativa de que o mundo só é natural a um ser a quem ele não pertença (BASSI, COELHO DE SOUZA \& KUBO, 2010).
} 
o conhecimento consiste primeiramente em habilidades, onde todo ser humano é um centro de percepções e agência em um campo de prática (INGOLD, 2010).

Assim, ao analisar aqueles que têm seu sustento baseado na interação com o ambiente tais como agricultores, Ingold questiona a visão Ocidental moderna do trabalho agrícola como uma ação humana de impressão de um desenho conceitual sobre um substrato de matéria-prima ou uma natureza subordinada, criando um processo de manufatura. Para o autor, o que acontece estaria mais próximo a uma noção de crescimento e engajamento mútuo:

\begin{abstract}
o trabalho que as pessoas fazem, em atividades como a limpeza de campo, plantio, capina e assim por diante, ou pastorando seu gado, não é literalmente fazer plantas e animais, mas sim estabelecer no meio ambiente condições para o seu crescimento e desenvolvimento [...]. Os seres humanos e os animais e as plantas que dependem para subsistência um do outro devem ser considerados como companheiros participantes no mesmo mundo, um mundo que é ao mesmo tempo natural e social. $\mathrm{E}$ as formas que todas estas criaturas tomam não são dadas em antecedência, nem impostas a partir de cima, mas emergem no contexto de seu envolvimento mútuo em um campo único e contínuo de relacionamentos. (INGOLD, 2000, p. 101, tradução própria).
\end{abstract}

Em sintonia, Norgaard (1987) demonstra como os agroecossistemas têm coevoluído a partir da interação entre sistemas biológicos e sociais, de forma que um depende da retroalimentação do outro, fazendo com que o conhecimento encarnado nas culturas tradicionais estimula e regula a retroalimentação dos sistemas biológicos que se desenvolvem também como um reflexo das sociedades que os compõe. Portanto, a percepção de que ação humana na agricultura é concomitante algo que acontece em um sistema de relações ecológicas e sociais, possui total ressonância com a agroecologia. Compreendida aqui de forma polissêmica como uma ciência, um conjunto de práticas e um movimento social (WEZEL et. al, 2009), a agroecologia envolve um conhecimento que emerge a partir da ação e interação localmente enraizada de seus atores. Estes conhecimentos surgem pela peculiaridade de composição dos ecossistemas ou das culturas a eles associadas, em uma dinâmica de potencialização da biodiversidade ecológica e sociocultural no desenho de sistemas de agricultura sustentável (CARMO; COMITRE; FAGUNDES, 2012).

Petersen e Dias (2007) ressaltam que a produção de conhecimento deve ser vista como atividades próprias do ser humano, indo de encontro com as abordagens positivistas e difusionistas que desvalidam os conhecimentos produzidos fora da metodologia científica, mostrando-se como formas antiecológicas e desumanizadoras de gestão do conhecimento. Essa forma de saber e fazer agrícola são uma expressão do exercício da inteligência criativa de populações rurais na construção de melhores ajustes entre seus meios de vida e os ecossistemas, gerando um conhecimento que integra saberes autóctones e acadêmicos (PETERSEN E DIAS, 2007). É também neste sentido que diferentes autores (PETERSEN, 2007; ABA,2007; PETERSEN et al., 2009; MOLINA, 2011; COTRIM; DAL SOGLIO, 2016; CANUTO, 2017) tem usado o "Construção do Conhecimento Agroecológico" não enquanto um conjunto fechado de informações, mas sim como um processo de geração, coleta e disseminação de aprendizados e 
saberes coletiva protagonizados por atores em interação e gestão de agroecossistemas.

Tem sido de especial interesse os conhecimentos desenvolvidos em processo de transição, ou seja, aqueles empreendidos por agricultores que se engajam na agroecologia como uma nova forma de se relacionar com seus ambientes e cultivos, gerando, portanto, saberes específicos e localizados a partir da sua experiência prática no mundo. A sistematização desses processos se torna valiosa para entender como a criatividade se expressa através de diferentes estratégias na mobilização dos elementos naturais, materiais e sociais de forma a ampliação da sustentabilidade ecológica e a autonomia social frente ao sistema alimentar hegemônico. Tal como propõe Gliessman (2009), a sistematização do processo de transição agroecológica deve levar em consideração as dimensões internas e externas ao sistema produtivo agropecuário, reconhecendo produção e reprodução são dinâmicas dialógicas dos agricultores familiares.

\section{Assentamento Filhos de Sepé: um novo mundo}

Tendo em vista o entendimento de que a construção do conhecimento acontece em um processo de envolvimento sensorial entre os indivíduos e seu mundo, é necessário apresentar, ainda que de forma muito breve, um pouco da trajetória de formação do Assentamento, visto que esse é parte crucial do mundo em que os atores aqui em questão estão situados. Mais do que isso, é ressaltar que a uma trajetória concomitante e paralela entre a criação do Assentamento enquanto um ambiente de vida e produção e a construção do conhecimento agroecológico dos agricultores ali residentes. Localizado no município de Viamão, distrito de Águas Claras, o Assentamento Filhos de Sepé é considerado o maior assentamento de reforma agrária no Rio Grande do Sul. O Assentamento foi fundado em 1998 e é composto por 376 famílias, oriundas de 115 municípios do estado. Sua história é bastante peculiar, pois envolve uma série de conflitos com os órgãos do Estado trazendo desafios e um contexto muito singular para as práticas produtivas das famílias assentadas. A área é rica em recursos hídricos, tendo dois arroios (Vigário e Alexandrina), um aquífero e a nascente de Águas Claras que abastece o Rio Gravataí, sendo, portanto, fontes hídricas importantes para o abastecimento das cidades do entorno. Essa abundância de água somada ao terreno plano com várzeas e banhados torna o local muito propício para o cultivo de arroz irrigado.

Os 9.450 hectares hoje ocupados por 376 famílias, eram uma propriedade particular que passou por diferentes donos, sempre tendo a produção de arroz irrigado em cultivo convencional como principal atividade. Sob a gestão dos proprietários anteriores foram realizadas distintas modificações na paisagem para potencializar a produção do grão, tais como obras de macrodrenagem em áreas de banhado, construção de estradas internas e canais laterais, a drenagem do Banhado dos Pachecos e a construção de uma Barragem, denominada de Barragem Águas Claras. Na década de 1960 o Departamento Nacional de Obras de Saneamento DNOS construiu um canal com $35 \mathrm{~km}$ de extensão ligado que hoje tem sido considerado um prolongamento do Rio Gravataí. 
Essas informações são relevantes de serem mencionadas porque ajudam a elucidar processos e elementos que vão influenciar o processo de transição agroecológica e construção do conhecimento dos agricultores, em especial destacam-se três pontos. Em primeiro lugar, ainda que ao longo dos anos a fazenda tenha sido fortemente adaptada para a produção de arroz irrigado, estas modificações consideravam um sistema de plantio convencional, com alto uso de agroquímicos e a gestão por um único proprietário. Portanto, um contexto muito distinto a realidade vivida após a implementação do Assentamento em que 376 famílias passam a conviver e co-gerir os recursos seja para produzir ou simplesmente viver neste local, desafios em parte previstos no parecer que indicava como inadequada a instalação rápida de um assentamento de tal porte no local².

Em segundo, o território do Assentamento Filhos de Sepé envolve duas áreas de interesse ambiental que acabam por incidir em uma série de condições e restrições para a permanência das famílias no local. A Área de Proteção Ambiental $\left(\mathrm{APA}^{3}\right)$ do Banhado Grande foi criada em outubro de 1998, enquanto ainda corria a documentação para a consolidação da fazenda para fins de reforma agrária e atualmente circunda o assentamento englobando vários municípios da região. Já o Refúgio de Vida Silvestre "Banhado dos Pachecos" (RVS) foi instituído em abril de 2002, através de uma negociação direta entre a Secretaria Estadual do Meio Ambiente - SEMA e INCRA que cedeu 2.543,46 hectares do território interno do Assentamento para a instalação desta Unidade de Conservação com o objetivo de preservar as nascentes do rio Gravataí e resguardar a fauna local ${ }^{4}$, em especial os últimos indivíduos do cervo-do-pantanal no Estado do Rio Grande do Sul. As diretrizes que compõem estas áreas fazem com que o uso da água da Barragem Águas Claras, o escoamento de efluentes para o canal ligado ao Rio Gravataí se tornam bastante controlados. Ainda que desde a safra de 2001/2002 havia iniciativas de cultivo de base ecológica no Assentamento, após uma sequência de problemas em que o plantio de arroz acarretou problemas na qualidade da água para abastecimento nas cidades do entrono, em 2008 a certificação orgânica passa a ser uma exigência para a permanência das famílias.

O terceiro ponto que se destaca como influente no processo de construção do conhecimento dos agricultores é o constante de conflito entre as famílias assentadas e órgãos do Estado, que de um lado atua como tutor das famílias envolvidas em processos de reforma agrária, por outro é um órgão fiscalizador e implementador da legislação ambiental. Essa duplicidade de papeis também se expressa em interesses distintos, às vezes contraditórios, que em muitas vezes agrava a condição de vulnerabilidade e marginalização das famílias. A instalação no local de quase 400 famílias sem a existência de estruturas de habitação ou serviços

\footnotetext{
2 "Parecer sobre a ocupação agrícola da área da propriedade da Incobrasa localizada junto ao Banhado dos Pachecos, Viamão - RS”, lançado em 1998, apud INFINDHA (2004) e DIEL (2011).

3 A APA do Banhado Grande atualmente é composta pelos Biomas Pampa e Mata Atlântica e ocupa 2/3 da bacia hidrográfica do rio Gravataí, englobando uma área de 136.935 ha, com áreas urbanas e de culturas agropecuárias, predominando o cultivo de arroz (SEMA, 2012).

4 Os ambientes de banhados localizados nas nascentes do rio Gravataí são áreas de fundamental importância para o abrigo da fauna residente e migratória de aves e os últimos indivíduos do cervodo-pantanal (Blastocerus dichotomus) sobreviventes em todo o Estado do Rio Grande do Sul (SEMA, 2012).
} 
básicos (água, luz, esgotamento, etc), somadas as restrições das áreas ambientais e a falta de assessoria técnica adequada deixou as famílias a própria sorte, fazendo com que durante os anos iniciais do Assentamento as estratégias encontradas pelas famílias acarretassem em violação das diretrizes colocadas. Os conflitos envolveram diferentes ações, criação de Termos de Ajuste de Conduta, prisões, retiradas de famílias, perdas de safras de arroz e a implementação de novos regramentos que impactaram e ainda afetam a vida e o trabalho das famílias. A produção agroecológica praticada desde o início do Assentamento por um grupo de agricultores, passa com o tempo a ser uma imposição legal em resguardo ao ambiente. A incorporação da agroecologia como tema da Agenda do MST auxiliou e qualificou o processo.

Atualmente, o Assentamento Filhos de Sepé a área total de 9.450 ha é segmentada por diferentes usos: a preservação ambiental através do Refúgio de Vida Silvestre "Banhado dos Pachecos" (2.543,46 ha), a Barragem de Águas Claras, uma área denominada Perímetro de Irrigação ( 1.600 ha) em que apenas 256 famílias têm direito a cultivar arroz e quatro setores de residência ( $A, B, C$ e D). O mapa a seguir (Figura 1) apresenta de forma esquemática o Assentamento Filhos de Sepé.

Figura 1 - Mapa ilustrativo do Assentamento Filhos de Sepé, Viamão, RS

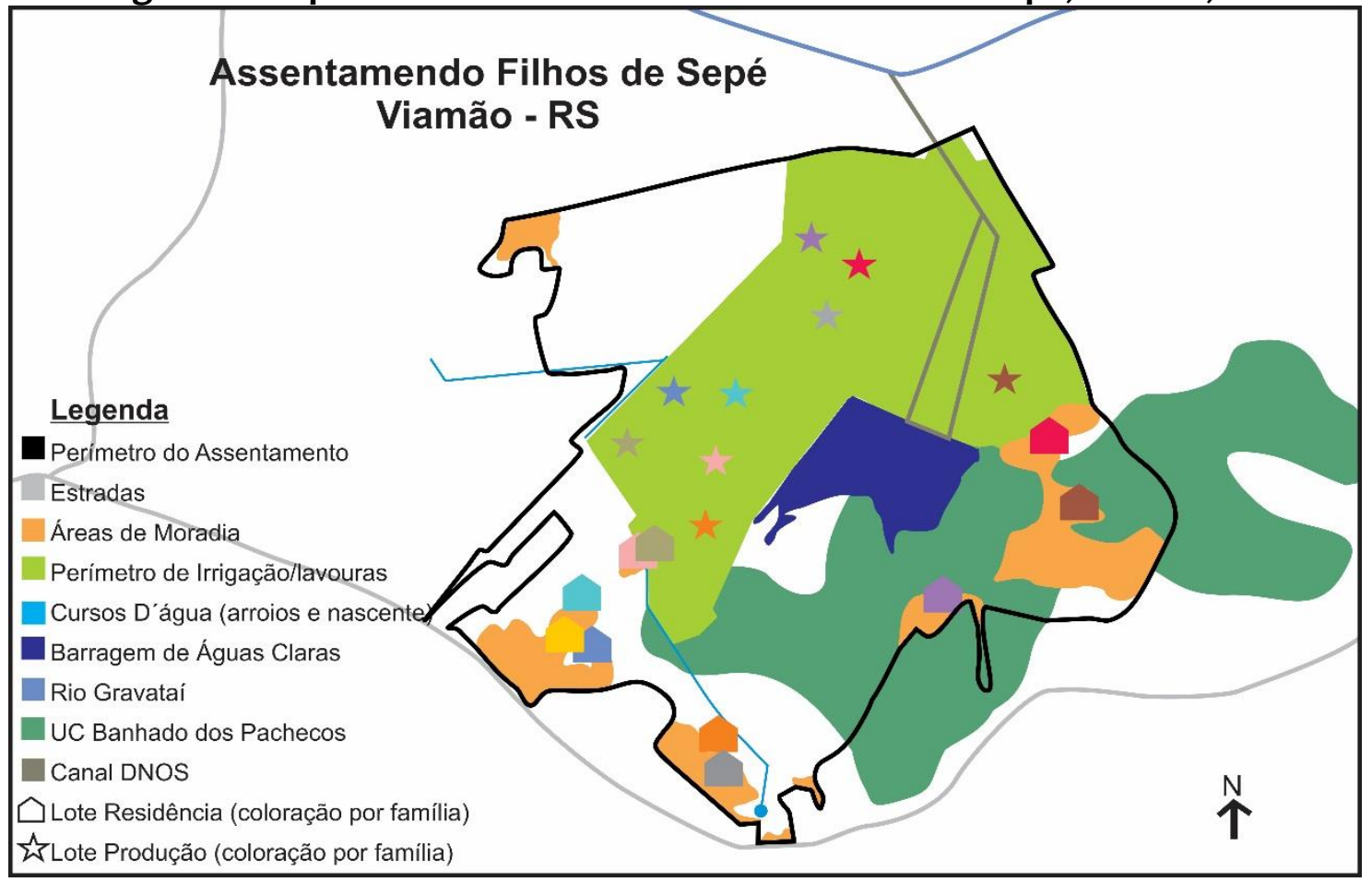

Fonte: Elaborada pela autora (2013)

\section{As Dimensões do Conhecimento}

Antes de apresentar de forma mais detalhada cada dimensão, é importante ressaltar que o processo de identificação destas dimensões envolveu a construção colaborativa de ilustrações. Essa metodologia de coleta de dados emergiu a partir da interação entre a autora e as famílias participantes como uma forma de materializar práticas e se compreender os conhecimentos envolvidos nos ciclos produtivos e reprodutivos. A prática que visava apenas esclarecer processos e 
situações vistas a campo, auxiliou a criar um ambiente descontraído, fazendo com que as famílias se sentissem à vontade para contar histórias, mostrar fotos e fazer seus próprios desenhos e esquemas. As famílias começaram a reconhecer pessoas e lugares: "bah, mas o fulano tu desenha bem direitinho!" "ali é a lavoura do Seu Beltrano né?", demostrando ser um canal eficiente de diálogo.

Além de servir como uma forma de coleta de dados para a pesquisa, o processo também criou uma potencial ferramenta de registro e sistematização do conhecimento agroecológico visto que ao discutir os desenhos com as famílias, as racionalidades das práticas de cada grupo de produção eram apresentadas e as heterogeneidades eram evidenciadas. Surgiam falas como "fulano faz assim, mas eu acho melhor fazer de tal forma" ou "o que tem que cuidar nesse momento é tal coisa". Além disso, ao criticar o desenho as famílias mostravam seu conhecimento e também evidenciavam o conhecimento da autora, ou melhor, a falta dele ao desenhar os processos de forma errada. Assim, vinham as falas "o implemento da máquina tá errado, essa aí é pros valos, para o preparo tu tem que usar grade ou um rolo faca, senão tu não arruma a terra, tu piora ela!" ou "a cor do marreco que ajuda na lavoura é diferente do marreco que vem comer depois, não é o mesmo" e "aqui tem que colocar um agricultor, tem que ter um assentado aqui senão vão achar que nos abandonamos a lavoura, essa época todo dia tem que cuidar!" Assim, os "erros" ajudavam a criar polêmica e debates que incentivavam os agricultores a reafirmar o seu saber. Houve uma real apropriação das ilustrações pela maioria das famílias estudadas, inclusive solicitando cópia dos desenhos ou ainda encomendando novos desenhos com os manejos específicos de sua prática.

Ressalta-se que o uso de recursos visuais não é exclusivo deste estudo, tendo sido utilizado por diferentes pesquisadores e agricultores que atuam nos processos de construção de conhecimento agroecológico. Conforme ressaltam Paranhos, Silveira e Nogueira (2007) os recursos visuais tem sido uma relevante ferramenta de registro, sistematização e comunicação de experiências que mais do que representar as técnicas, ilustram os processos de transição agroecológica implementados pelos agricultores. Uma vez que os materiais refletem a realidade vivida pelos agricultores, estes se tornam uma poderosa ferramenta de resgate dos seus conhecimentos, história e cultura (PARANHOS, SILVEIRA E NOGUEIRA, 2007). Petersen (2007) complementa ao argumentar que enquanto matéria crítica ao enfoque científico e os fundamentos conceituais e metodológicos do paradigma convencional de desenvolvimento rural, a Agroecologia tem como desafio aprimorar os métodos e ferramentas para a construção do conhecimento, buscando romper com o sentido vertical e unidirecional do difusionismo tecnológico. Assim, a criação de canais horizontais de diálogo entre os conhecimentos dos diferentes atores torna-se imprescindível, aliando teoria e prática e permitindo "erigir metodologias-ponte entre os procedimentos intuitivos, integradores e não lineares de produção de conhecimento dos (as) agricultores (as) e os procedimentos racionais, analíticos e lineares dos (as) técnicos (as)" (PETERSEN, 2007, p. 9).

Assim, é após diversas versões que os desenhos foram se transformando, qualificando e até chegarem nas ilustrações aqui apresentadas. A Figura 2 refere-se as dimensões da Lavoura e do Corre, podendo ser entendida também como um Calendário do ciclo de atividades da produção agroecológica do arroz a partir da 
perspectiva dos assentados. O desenho do Habitar que (Figura 3) surgiu a partir da crítica das famílias, que diziam que os ciclos que compõe a ilustração anterior falavam das atividades ao longo do ano, mas não davam conta de demonstrar como uma lavoura influencia a outra, a distância das casas ou a relação com o Refúgio da Vida Silvestre, elementos entendidos como essenciais para os atores. etc. Entendemos que de certa forma, a crítica era de que, ainda que uma leitura temporal dos processos produtivos fosse interessante, ela precisava ser acompanhada de uma leitura espacial onde a localidade, os agroecossistemas e o modo de vida também pudessem ser representados. Após as figuras apresenta-se os dados referentes a caracterização de cada dimensão em debate com a literatura.

Figura 2 - As Dimensões do Conhecimento: Lavoura e Corre

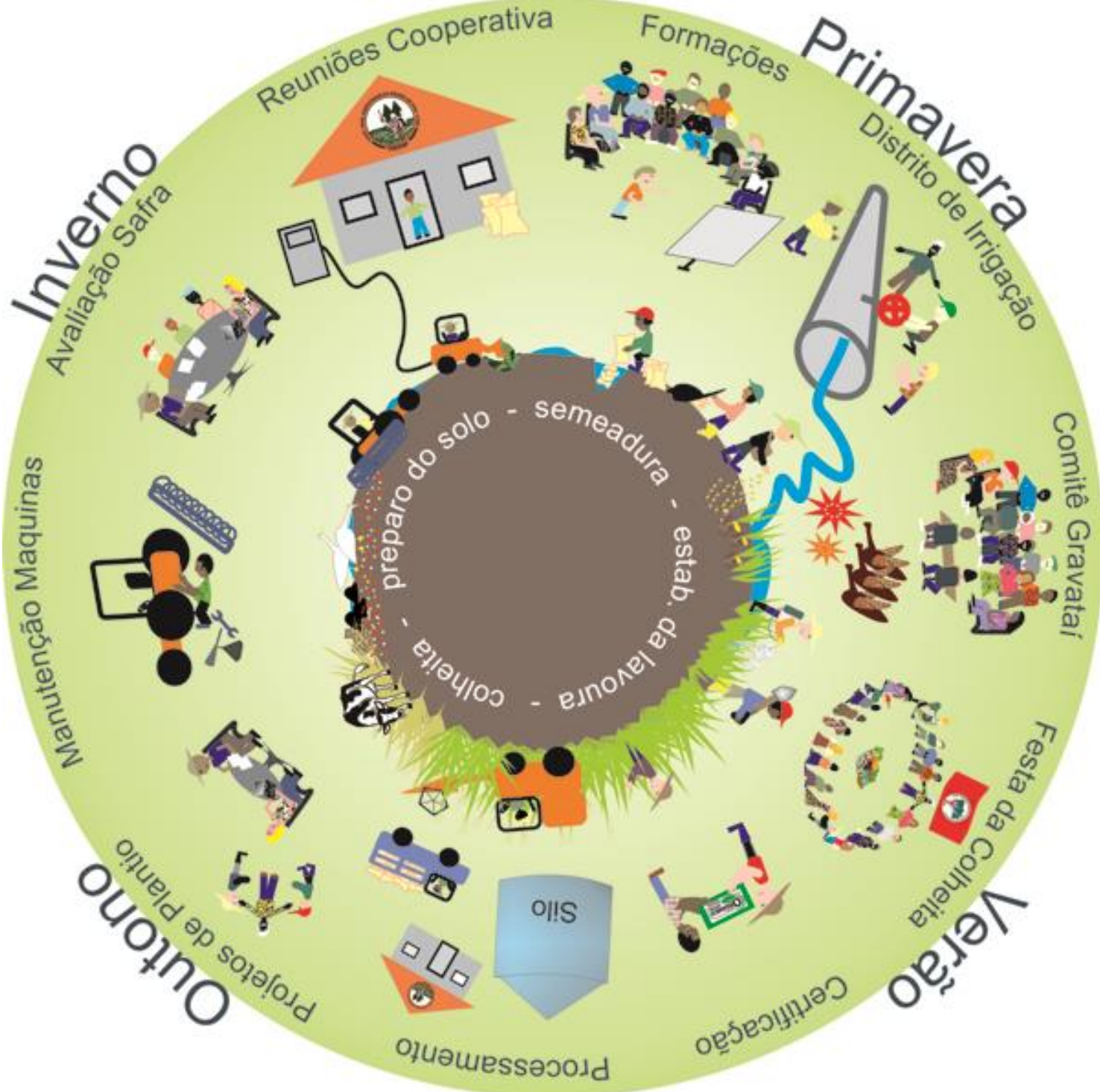

Fonte: Autoria coletiva entre a autora e os agricultores assentados (2013). 
Figura 3 - Dimensão do Conhecimento: o Habitar

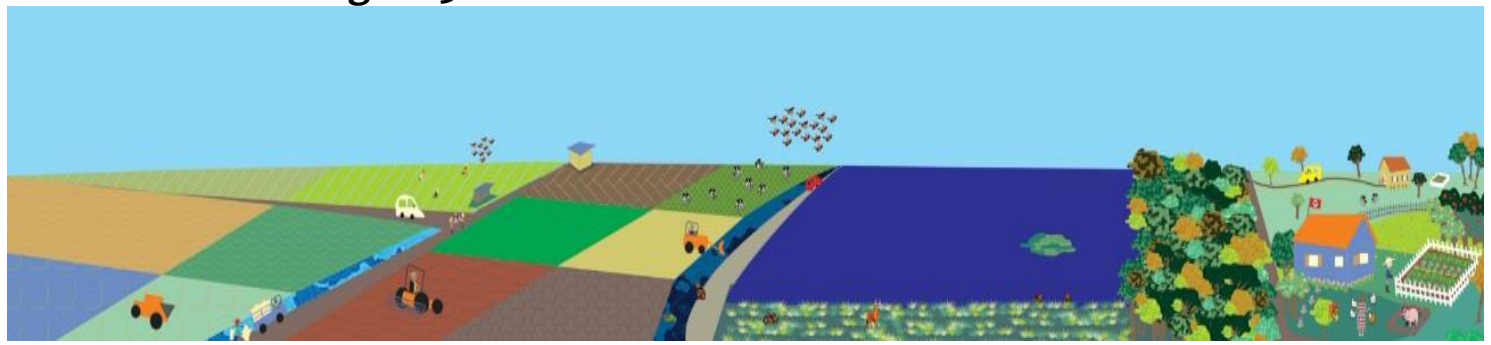

Fonte: Autoria coletiva entre a autora e os agricultores assentados (2013).

\subsection{A Lavoura}

As famílias que compõem o Assentamento têm sua origem em diferentes regiões do estado do Rio Grande do Sul, o que significa também uma diversidade de trajetórias em termos de cultura, experiências com agricultura e o meio natural. A grande maioria das famílias nunca havia cultivado arroz, menos ainda, arroz agroecológico. Entre os entrevistados, apenas 2 tinham experiência prévia com produção de arroz, tendo apreendido com seus pais o ofício. Assim, a lavoura é a dimensão que envolve os conhecimentos desenvolvidos pelos agricultores para interagir com os elementos naturais (solo, água, planta, clima, etc.) e produzir o grão, um processo de aprendizado que se deu na prática entre tentativas e erros. A produção acontece através do grão pré-germinado, o que envolve uma safra de ciclo anual que pode ser dividida em 4 etapas: 1. preparo do solo; 2 . germinação das sementes e semeadura; 3. estabelecimento da lavoura e maturação; 4. colheita. $O$ processo acontece de forma cíclica, sendo o final de uma fase o início de outra. Ainda que a duração de cada etapa e os cuidados necessários variem levemente de acordo com a variedade de arroz cultivada, todos tendem a seguir um percurso similar.

O preparo do solo vai do período pós-colheita em meados de abril até a semeadura na primavera, a grande preocupação é fomentar a fertilidade do solo e para tanto, diferentes estratégias podem ser mobilizadas. Alguns agricultores aproveitam a resteva da safra anterior e incorporam a palha do arroz colhido no solo para incrementar a produção de matéria orgânica. Outros criam animais, em especial gado ou marreco-de-pequim, de forma que o esterco eliminado enriqueça a adubação do solo. O uso de marreco-de-pequim no cultivo de arroz é uma prática é de origem chinesa que foi introduzido no Assentamento pelos "Catarinas" 5 e é vista como uma possibilidade interessante pois cumprem diferentes funções conforme esclarece o agricultor Telmo "As marrecas preparam a terra e comem o inço tudo! Comem tudo que é bichinho, estercam na água e já é adubo".

Apesar de ser um consenso entre as famílias a eficiência deste consórcio, poucas utilizam, pois, ela envolve um alto custo e demanda cuidado com os animais devido a predadores ou roubos nas lavouras. A fertilidade do solo também é incrementada com a adubação, podendo esta ser de composto orgânico como

\footnotetext{
5 Maneira de se referir aos plantadores de arroz, na sua maioria oriundos do Estado de Santa Catarina, que no início da formação do Assentamento ocupavam as áreas de lavouras em parcerias com os assentados. Ainda que essa atuação fosse ilegal e com o tempo deixou de acontecer, a experiência desses plantadores teve relevância para a construção do conhecimento dos assentados.
} 
cama de aviário, pó de rocha ou ainda preparados biodinâmicos. A estratégia mais econômica e menos trabalhosa é simplesmente deixar a área em pousio, ainda que não contribua muito para a fertilidade do solo. O manejo do solo é um elemento chave na agroecologia, entendendo que a qualidade do solo terá consequências diretas na qualidade dos alimentos ali cultivados. Primavesi (2008) argumenta que entre as formas de manejo do solo agrícola, o agroecológico é a forma que mais depende da sabedoria que cada agricultor desenvolve com sua experiência e observação do local, buscando como condição ideal a maior presença de formas de organismos interagindo entre si e com elementos minerais e orgânicos do solo. Assim, entende-se que os agricultores que buscam estratégias de consorciamento com os animais são aqueles mais próximos a condição ideal proposta por Primavesi (2008), visto que buscam aumentar a vida no solo e a diversidade de nutrientes mobilizados. Ainda que é importante reconhecer que estas são as estratégias mais custosas economicamente e trabalhosas, portanto o uso de outras formas de manejo não pode ser tomado como uma falta de conhecimento, mas quizá a única alternativa viável diante das condições materiais daquele agricultor.

A partir de setembro, a lavoura começa a ser sistematizada, prática também introduzida pelos "Catarinas" em que o terreno é nivelado para que possa ser totalmente inundado, permitindo um bom fluxo do sistema de irrigação. Os agricultores concordam que o preparo adequado do solo é um fator essencial, "o que mais ajuda na produção é o preparo do solo na época certa" diz Alceu. Dentro de cada lote as canchas podem ser separadas por taipas permanentes ou ainda em curvas de nível dependendo da topografia do terreno. A sistematização é feita de forma mecanizada por todos assentados, aqueles que possuem maquinário acabam tendo uma redução de até $60 \%$ nos seus custos de produção, além de uma alternativa de renda através da prestação de serviço a outras famílias. O preparo secundário garante o nivelamento do terreno e o destorroamento, ação feita com o uso das grades de disco e de dente. Ainda que compreendamos que a mecanização pode trazer impactos negativos em relação a compactação dos solos, devido ao tamanho das áreas o uso dos equipamentos é visto como necessário pelos agricultores. É importante reconhecer, que o uso dos maquinários também é parte do processo de construção do conhecimento, pois se tornam ferramentas na mão dos agricultores requerendo um determinado tipo de saber e manipulação, conforme fica evidente na fala do agricultor Alfredo "o implemento da máquina certo da máquina nos também tivemos que aprender. Para o preparo (do solo) tu tem que usar grade ou um rolo faca, senão tu não arruma a terra, tu piora ela!"”.

Após o solo estar sistematizado, inicia o período de germinação das sementes e semeadura em que a lavoura é alagada por até quarenta dias antes de ser semeada, uma estratégia que busca aumentar o processo de decomposição de matérias orgânicas e fermentação no solo. Quando se aproxima a época do plantio, a germinação é feita com as sementes ainda nas sacas. As sacas são colocadas no final da tarde em valas próximas as lavouras para que em contato com a água possam germinar, geralmente pernoitam e passam algumas horas imersas antes de serem retiradas e colocadas sob uma lona no sol para brotarem (Figura 4 e 5). 
Figura 4. Sacas de arroz em vala germinando; Figura 5. Exemplo de como ficam os grãos de arroz sob lona no sol para estimular brotação; Figura 6. Semeadura a

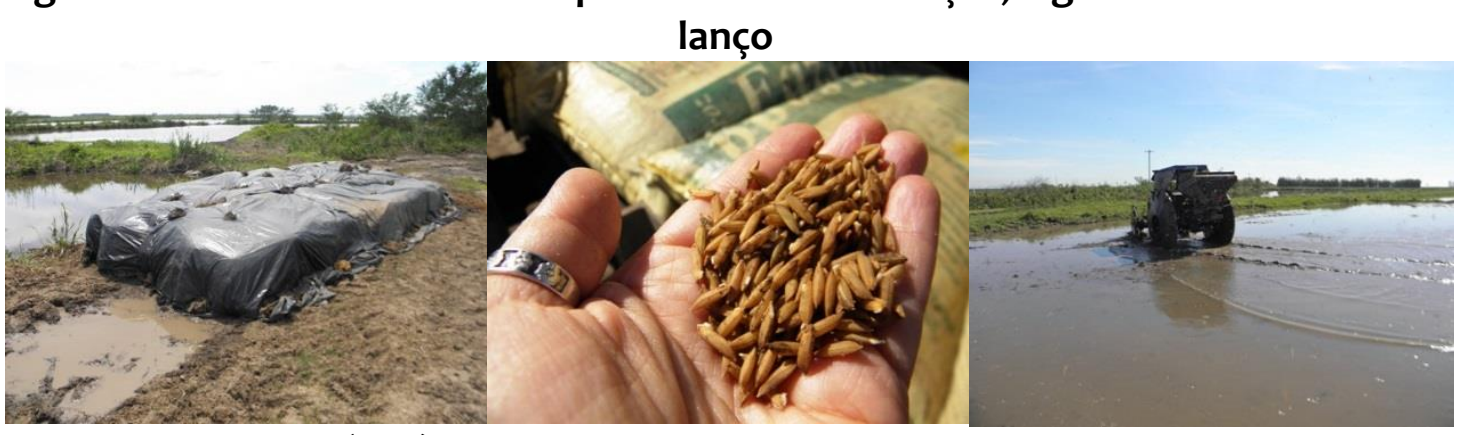

Fonte: Autoria própria (2013)

Essa fase requer muita atenção porque são necessários cuidados que garantam as condições muito específicas de umidade, temperatura e oxigênio para que a semente possa germinar. Qualquer alteração pode levar a resultados indesejados, como o apodrecimento ou secura excessiva da semente, o que inviabiliza a germinação. Após um período de 24 a 36 horas as sementes são semeadas à lanço (Figura 6) ou em linha (manual), momento onde alguns agricultores optam por escoar toda a água da lavoura e outros optam por deixar uma pequena lamina d'água. As sementes recém-germinadas atraem a atenção de aves que tentam se alimentar através dos grãos germinados, levando os agricultores a passar tempo integral afastando os pássaros da lavoura.

Tem que cuidar direto, uns dez dias. Tem que ficar lá dia e noite! Tem rodear toda a lavoura, porque senão vem um bando de passarinho e come 10 hectare de arroz num dia! (Telmo, agricultor assentado)

Para que a lavoura possa se estabelecer, é necessário um adequado manejo da água que atua não só para suprir a necessidade de irrigação da planta, mas também é como controle biológico para plantas indesejáveis como capim-arroz, arroz vermelho e preto e insetos predadores.

O herbicida do orgânico é a água, porque é o controle teu [...]. Tu semeia ele, tem o tempo de semeadura, tu semeou vamos dizer que esgotou a lavoura. Daí vem o caso do controle do bicho, do caramujo. Tu tirou a água, tu secou a lavoura, tu vai ficar com a tua lavoura $5 \mathrm{dia}, 7 \mathrm{dia}$ tu pode deixar, tem gente que deixa mais ainda, deixa torrar. Tu deixa uma semana já ele vai querer rachar tipo assim ó (aponta para o chão), com uma rachadura! Então o bicho que tinha ali e coisa foi [...]. Pode vim o caramujo mais futuramente mais tarde, mas a hora que vir, o arroz já vai ta forte! Ele só come até um ponto, quando o arroz ta mole ainda, durante quinze dias. Depois ele não vai comer mais! (Nestor, agricultor assentado)

A descrição de Nestor é importante porque mais do que explicar o que acontece na época da semeadura, demonstra como o seu conhecimento sobre o processo se dá através da observação de como os elementos naturais ali presentes - o grão do arroz, a água, o solo, o caramujo, sol interagem e desencadeiam fenômenos. A narrativa exemplifica como a construção do conhecimento agroecológico tem acontecido conforme propõe Ingold (2000), em um 
engajamento em um ambiente material e simbólico em que os agricultores criam processos de atenção aos sinais que se revelam na paisagem para então desenvolver as habilidades necessárias ao manejo. A fase seguinte se refere ao estabelecimento da lavoura, momento em que o manejo é centrado em garantir um bom desenvolvimento das plantas e maturação do grão, sendo para tanto utilizados alguns insumos ou preparados biodinâmicos conforme comentam os agricultores:

A gente faz fungicidas caseiros com cebola e alho, funciona bem! (Alceu, agricultor assentado).

Tem um produto que a gente bota no chifre da vaca e enterra numa terra virgem. Aquilo funciona!! É um fungo que tu coloca na semente quando vai plantar, a gente inocula quando a semente ta germinando. A gente inocula e da uma fortidão na raiz e o pé já sai valendo! É impressionante! Tem também uns produtos que a gente compra de um cara lá de Tapes, que faz o biodinâmico. Mas é caríssimo os produtos... A gente pega o esterco do animal, mas é montanha de esterco! Daí de ponta em ponta coloca esses produtos e deixa tapado. Daí ele vai fermentando ali. Depois tu pega o esterco, coloca num saco e vai e coloca de ponta em ponta na lavoura. É um tipo de um chá, porque ele funciona como um chazinho só que pra planta [...]. Tem um outro que a gente faz que é com a urina da vaca, daí coloca num tambo, põe mel, açúcar mascavo e mais um monte de coisa, daí faz uma fermentação e depois coa. Daí bota numa bombinha nas costas, mas é uma porcentagem muito pouquinha que tem que botar, senão queima! Com o vento tu toca como daqui lá naquela palmeira lá! Essa é a nossa ureia biofertilizante, é muito bom e funciona! (Ernesto, agricultor assentado)

A partir de meados de janeiro inicia o período de colheita de forma mecanizada, sendo necessária a drenagem do solo. Quando se considera o ciclo do cultivo como um todo, o elemento mais citado com primordial no processo de construção do conhecimento é a necessidade de observação. A fala do agricultor Horário ilustra bem esse processo:

Se você vai plantar arroz tem que estudar a planta do arroz primeiro, como é que vai lidar com uma coisa que você não conhece? Você tem que conhecer a planta, desde a semente, produzir a semente, começa mais cedo ainda. Não é somente pegar a semente e largar no chão, tem um processo para ser seguido. Não é uma receita! Eu quero olhar a planta, de onde é que ela vem, como é que ela sai do grão, com que energia ela sai, como é que ela se comporta daqui a pouco. (Horácio, agricultor assentado).

As afirmações vão ao encontro da argumentação de Bracagioli (2003) de que a implementação da Agroecologia não deve seguir a lógica dos "pacotes tecnológicos", mas precisa ocorrer de forma descentralizada e localizada, respeitando as características peculiares a cada agroecossistema. O tema também é discutido por Canuto (2008) que destaca a observação como um diferencial da agroecologia em relação à agricultura convencional que promove um esforço de simplificação do conhecimento através de pacotes e manejos com receitas, tornando o papel da observação um acessório. É neste sentido que o autor afirma 
que o conhecimento agroecológico é "de código aberto, livre acesso, modificação e aplicação" (CANUTO, 2008).

\subsection{O Corre}

Durante o trabalho de campo, frequentemente escutava-se falas como "quem planta no grupo é o Fulano, Beltrano faz o corre", ou ainda ao tentar agendar encontros recebíamos como justificativa de impossibilidade "amanhã não dá, tenho corre!". Assim, compreendeu-se que essa dimensão também é percorrida ao longo do ano de forma paralela aos acontecimentos da lavoura, mas que envolve as reuniões e atividades necessárias para viabilizar o plantio, o processamento e a venda do arroz. É o que Gliessman (2009) chama da dimensão externa ao sistema produtivo agropecuário pois abarca toda a rede de relações sociais vinculados ao processamento e comercialização do grão, questões burocráticas e financeiras, bem como a participação em espaços organizativos e políticos. Diferente da lavoura em que a interação central se dava entre o ser humano e os elementos naturais, aqui as dinâmicas envolvem outros atores coletivizados de distintas formas, bem como documentos, dinheiro e prestações de serviço. Portanto, requerem a participação em diferentes instancias e a interação com uma ampla rede de atores, ilustrada na Figura 4, que em diferentes medidas afetam o processo de produção e comercialização do arroz agroecológico.

Diante disso, adiantamos que a centralidade dessa dimensão para o processo de construção do conhecimento agroecológico nos parece cingir dois eixos centrais. $O$ primeiro se refere a necessidade de que os atores aqui em questão, se tornem mais do que agricultores plantadores, mas que passam também a compreender questões referentes a administração, contabilidade, gestão, entre outras funções, de forma que possam em diferentes medidas dominar processos de governança coletiva de recursos e demandas institucionais. Dado um contexto de significativa escassez de recursos econômicos e técnicos para implementar tais processos, a criatividade e a organização coletiva tonam-se os alicerces do modus operandi. Em suma, seria o que Ploeg (2008) percebe como uma estratégia de afastamento das relações de dependência do mercado e da logica agrícola convencional, permitindo que os agricultores possam encontrar soluções através do aumento da eficiência técnica e da autonomia na base de recursos. O segundo eixo de contribuição é que estes coletivos e instituições que os agricultores compõem e interagem acabam por se constituírem em grandes fóruns de trocas de saberes e aprendizagem, criando um significado e relevância para além das funções formais que executam. 
Figura 4 - Rede de relações sociais no cultivo de arroz agroecológico

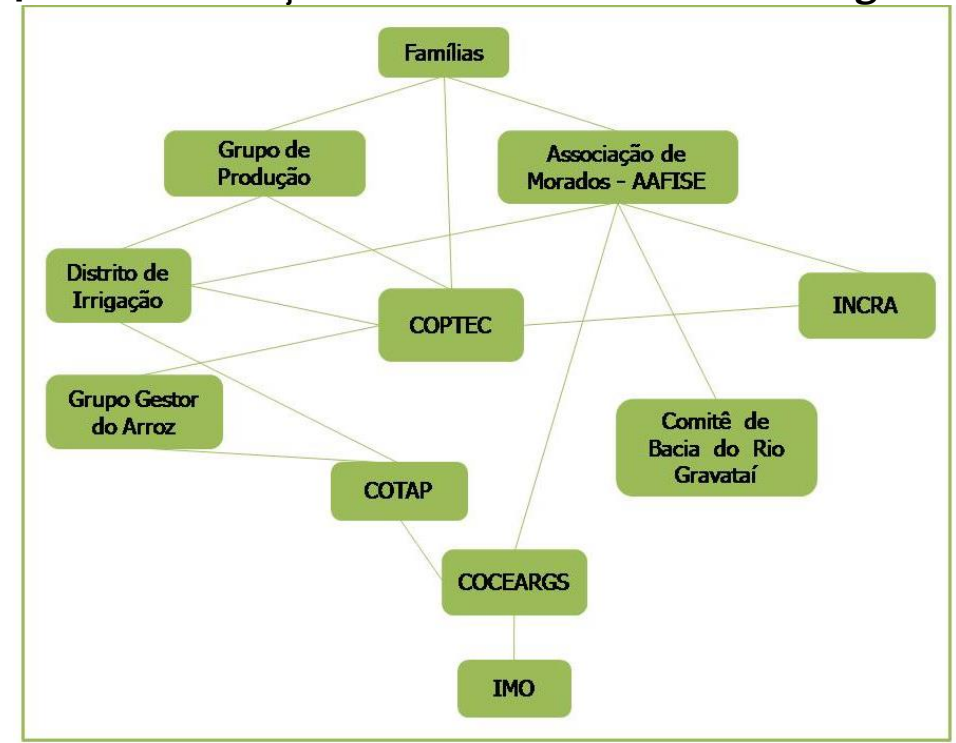

Fonte: Elaborada pela autora.

Tendo em vista o foco deste artigo, salienta-se alguns desses espaços e demandas, de forma a exemplificar a diversidade de saberes a serem desenvolvidos para que o fluxo de demandas de cada safra seja atendido. Inicia-se abordando o processo de elaboração dos projetos, um requisito do INCRA desde 2004 que confirma ou não a possibilidade de plantio na safra corrente. O processo acontece durante o inverno, paralelo ao período de preparo do solo, através do lançamento de um edital ${ }^{6}$ de abertura de safra pelo INCRA. A apresentação dos projetos acontece através do preenchimento de um formulário e as famílias interessadas em plantar comparecem e apresentam seus documentos e informações ao técnico, que auxilia no preenchimento do formulário. A atuação do técnico á altamente relevante, não só per ele ter os equipamentos necessários, mas porque o preenchimento do "projeto" envolve elementos bastante técnicos nem sempre de domínio de um agricultor, tais como a localização georeferenciada da área, variedade a ser plantada e estimativa de colheita por área.

Aqui não se pode deixar de problematizar que ainda que se compreende a necessidade de organização demandada pelo Estado, o nível de burocratização dos processos requer um conhecimento formal e letrado que é de difícil conciliação com a realidade. Entre os assentados entrevistados, a maioria dos agricultores cursou no máximo até a $5^{a}$ série, sendo a exceção novamente o mais jovem entre eles que chegou a cursar um $2^{a}$ grau técnico. Assim, este novo contexto também pode se tornar uma restrição e uma alta dependência do técnico para a execução de procedimentos básicos. A nova geração que está crescendo no Assentamento tem maior acesso à educação em relação aos seus pais, muitos inclusive frequentam

\footnotetext{
${ }^{6}$ No edital são descritas as diretrizes que os assentados devem seguir para cultivar o arroz na safra e as etapas do processo que envolve: a apresentação dos projetos; avaliação e julgamento; publicação inicial; contestação dos projetos reprovados, publicação final dos projetos aprovados e reprovados e assinatura do termo dos contratos de irrigação. A análise dos projetos é realizada por uma comissão composta por representantes do INCRA, do Assentamento, da assistência técnica e dos órgãos ambientais, ainda que, segundo nossos interlocutores, estes não tenham estado presentes nos últimos anos.
} 
cursos de graduações de nível superior, o que faz com que os filhos muitas vezes sejam quem ajuda nas anotações ou ainda a fazer as "coisas de computador". Esse contexto, ressalta a relevância de políticas públicas aquelas fomentadas pelo Programa Nacional de Educação na Reforma Agrária - PRONERA, que segundo dados IPEA (2015) tinha o envolvimento de 164.894 educandos através de 82 instituições de ensino localizadas nos diferentes estados do país. Um dado complementar é apresentado pelo próprio MST, que indica que 5 mil trabalhadores estavam cursando cursos técnicos de nível médio (como Administração de Cooperativas, Saúde Comunitária, Magistério e Agroecologia) e cursos superiores e especializações (como Pedagogia, Letras, Licenciatura em Educação do Campo, Ciências Agrárias, Agronomia, Veterinária, Direito, Geografia, História) através de parcerias com universidades públicas (MST, 2010). Ainda que os dados sejam positivos, são módicos frente a demanda. Portanto, é preciso considerar que o avanço da construção do conhecimento agroecológico também passa pelo fomento a alfabetização e inclusão digital dos agricultores.

Outro elemento presente na elaboração dos projetos, é o requerimento de que o plantio aconteça através de um processo coletivizado - os grupos de produção. Assim, as 90 famílias que estiveram envolvidas com a produção agroecológica do arroz na Safra 2011/2012 estavam organizadas em 9 grupos de produção, sendo estes mobilizados a partir de afinidades pessoais, proximidade de áreas no Distrito de Irrigação e dinâmicas de trabalho. É a partir desses grupos que os agricultores atuam com representações em outras instâncias tais como o Distrito de Irrigação e o Grupo Gestor do Arroz. Estes espaços são essenciais, não apenas pelas funções formais que executam, mas porque se constituem como grandes fóruns de trocas de saberes e aprendizagem. Um exemplo é a Avaliação da safra, atividade anual que acontece em dois momentos: uma primeira etapa local, no Assentamento e um momento regional onde participam todos os assentamentos que compõe o Grupo Gestor do Arroz.

$\mathrm{Na}$ avaliação local, os representantes de cada grupo de produção são convidados a trazer a análise do grupo sobre a safra levantando pontos positivos e negativos. Entre as questões a serem melhoradas está o alto custo da produção, em especial necessidade de contratação de horas/máquinas e os custos de secagem. $O$ atraso no manejo da terra e plantio foi colocado como das causas da baixa produtividade, aliada a terras "ruins" como áreas muito arenosas ou pouco férteis. Os relatos sugerem uma grande variação de produtividade entre os lotes com resultados que vão de $40 \mathrm{sac} / \mathrm{ha}$ a $80 \mathrm{sac} / \mathrm{ha}$. A justificativa pelas diferenças de produtividade é atribuída à baixa fertilidade do solo. Um ponto visto como positivo por todos é o novo sistema de pagamento da água. Nos anos recentes foi acordado que juntamente com os projetos de plantio, os agricultores devem incluir um documento autorizando a cobrança da taxa da água no valor de 5 sacas de arroz em casca limpo e seco por hectare cultivado na safra. O montante é descontado em arroz diretamente no secador da COOTAP7 no final da referida safra.

O sistema tem ajudado a acabar com problemas históricos de inadimplência na conta de água e garantido uma receita para o Distrito de Irrigação. A solução

7 Cooperativa dos Trabalhadores Assentados da Região de Porto Alegre - COTAP, entidade organizadora dos assentados na região. 
encontrada é o que autores como Polanyi (1944), Ploeg (2009) e Sabourin (2011) definem como uma estratégia camponesa de circulação de recursos em sistemas não mercantilizados, visto que os pagamentos em sacas de arroz criam um sistema de troca operacional e uma dinâmica de reciprocidade que permite que a solidariedade e os laços sociais se sobreponham ao valor de mercado do grão, evitando a busca do lucro, lógica essencial das relações de mercado. Ao centralizar o recebimento das sacas e retornar o valor do produto vendido ao Distrito de Irrigação, a COTAP também se utiliza um sistema de redistribuição. Em vista disso é que Sabourin (2011) sugere que o objeto de compartilhamento tem menos relevância do que as ações entre os atores que geram valores de confiança a responsabilidade pelos recursos limitados, de forma que acaba por criar um sentimento de pertencimento ao grupo.

Criado em maio de 2005, como uma associação civil com a participação compulsória dos agricultores, o Distrito de Irrigação vem suprir uma demanda de gestão da água utilizada pelos plantadores, conforme explicam Alfredo e Ernesto:

Como a água é o que precisa, um precisava de água ia lá e largava água pra sua lavoura, daí tirava água do outro. Daí o outro ia lá trancava e pegava para si, aí era sempre uma baderna. Dai começamos a tirar uma pessoa que fizessem isso, nos pagava um dinheiro pra ela e ela coordenava. Era um jeito de eu não dizer "eu preciso de mais" ou outro dizer "não! essa é tua parte, e aqui a parte do outro"[...]. A partir disso a gente foi evoluindo, evoluindo até criar um Distrito. (Alfredo, agricultor assentado).

Os valos foram feitos para um dono só, mas hoje somos 376. Então nós não podemos plantar todo mundo na mesma época. Temos que ter um planejamento. Se meu grupo plantou aqui, tipo na área da nascente onde nos temos 300 hectares. Se eu planto hoje 2-3 lotes, daí o vizinho tem que esperar uns 4 dias para plantar os lotes dele. Porque quando eu não querer mais água aqui, o outro vai ocupar ela lá na frente! Tem que ser assim, água programada, senão não chega para todo mundo! (Ernesto)

Ainda que as suas funções oficiais sejam a administração, operação e manutenção da infraestrutura de irrigação de uso comum, o Distrito de Irrigação é mais que tudo um importante espaço de aprendizagem coletiva sobre governança e gestão dos recursos. As reuniões do Distrito são os espaços onde se percebe uma maior interação e troca de experiências entre os agricultores assentados, que ao falar de suas terras e pedir ajuda aos outros agricultores, ou ainda comentar situações ocorridas nas lavouras de outros agricultores demonstram como a experiência de um, contribui para o outro. Nesse sentido, a participação ativa no Distrito é de suma importância, tanto para a gestão da água como recurso essencial, mas também como espaço coletivo de construção do conhecimento agroecológico. A cada dois anos, uma assembleia é feita para eleger um novo Conselho Gestor, com representantes de todos os setores e grupos de produção. Um acordo informal foi feito para que a memória do trabalho e o conhecimento acumulado no Distrito possam ser mantidos e preservados na alternância da gestão, como comenta Ernesto: 
Nós fizemos um acordo para não trocar tudo de vez, porque tem que ficar uns que sabem para ajudar os outros a ir pegando o ritmo! (Ernesto, agricultor assentado).

Entre as decisões e ações que cabem ao Distrito, está por exemplo, o corte de área de plantio de alguma família, ação que pode ser necessária para suprir as necessidades de irrigação da maioria das lavouras sem exceder o limite acordado com o Estado de uso da água. Outra questão problemática que surge no Distrito são os casos de famílias com área dentro do perímetro de irrigação que não irão plantar, mas que tem áreas localizadas no meio de lotes que terão plantio, fazendo com que o Distrito tenha que arcar com os custos de preparação destas lavouras, pois delas dependem outros agricultores devidos às conexões do sistema de irrigação. Para se ter uma noção da precariedade do sistema, $60 \%$ do recurso do distrito tem sido gasto com limpeza e manutenção dos canais. A partir do Distrito, também tem sido encaminhada compra coletiva de equipamentos, uma ação importante para reduzir custos e mais um elemento para gestão do grupo. Nesse caso, as questões discutidas anteriormente da busca da autonomia e controle da base de recursos também são exemplificadas aqui.

Essas estratégias também têm sido implementadas através da atuação da COTAP, que ha cerca de 5 anos a COTAP tem servido como uma subsidiária e articuladora para os grupos, fornecendo o recurso para a compra do óleo diesel, as sementes para o cultivo, conforme explica o agricultor Ernesto:

Nós fizemos uma boa negociação com a COTAP, porque o pessoal tem tudo que pagar a água e agora ta todo mundo voando baixinho [...] não tem dinheiro. Então ela dá um dinheiro adiantado que nos botamos em hora/retro. Manda dinheiro pra nós comprar diesel, então ta bom! Ta bem encaminhado, porque assim não falta dinheiro. Antes eu buscava dinheiro lá na nossa região, porque aqui tinha muitos exploradores, os "Catarinas" e esses grandes engenhos aqui exploravam o nosso pessoal, davam dinheiro, mas pegavam quase todo o produto para eles. Hoje a gente financia pela Cooperativa e ela é quem fica com nosso produto (Ernesto).

O que é importante de ressaltar desta fala é que através da organização coletiva, em grupos de produção, Distrito e Cooperativa os agricultores conseguem melhor as condições materiais, financeiras e logísticas para realizar a sua produção, criando cada vez mais um processo de autonomia frente ao Estado e a instituições privadas de crédito e insumos. Um último elemento que não se pode deixar de mencionar é em relação ao processo de certificação de produto orgânico, feito até então por um mecanismo de auditoria promovido pelo Instituto de Mercado Ecológico - IMO. Entre os requerimentos solicitados durante as visitas de inspeção está o caderno de campo em as ações efetivadas na lavoura devem estar registradas. Ainda que seja um requerimento, o registro e controle de suas atividades se torna altamente relevante para o processo de construção do conhecimento como ressaltam os próprios agricultores:

Aqui é tudo anotadinho [...] a gente tá até aprendendo com esse tipo de coisa ai. Aprendendo o que? O que a gente não fazia! A gente sabia as coisas, mas não anotava. Agora não! O dia que tu bota a semente na água, que tu tira, que tu vai semea, é tudo marcadinho, o que tu bota, quantas pessoa 
trabalham, o que é feito lá em baixo, o que é feito no preparo da terra, quantos trator, é tudo marcado! Porque o assentado tem que saber (Nestor).

A minha função do grupo é que eu cuido dos livros de campo. Quando nós lutava com o químico não fazia nada de anotação, nós não fazia nada. Agora não, é tudo anotado! Hoje se entrou na lavoura, se nos gradeamos tem que anotar tal dia, tal lote. E isso vai chegar lá na certificadora. (Clóvis).

Ainda que a anotação das atividades seja um requerimento da Certificadora, ao reconhecer o procedimento como relevante as famílias sugerem que o "estar atento" discutido também na dimensão da Lavoura, se faz presente e pertinente aqui também. Logo, podemos concluir que a atenção e observação são um exercício constante em todas as esferas de construção do Conhecimento Agroecológico: ecológico-produtiva, socioeconômica e sócio-política. Essa questão tem sido comentada por outros autores, tal como Weitzman (2007) que apresenta relatos de educadoras comunitárias descrevendo como a prática do registro em cadernos de campo tem contribuído para construção do conhecimento, revelando que as anotações ajudam a apresentar e comunicar o trabalho para outros, bem como a avaliar o próprio trabalho, possibilitando que erros ou acertos possam ser identificados.

Por outro lado, ao estruturar o sistema organizativo e produtivo em dinâmicas cooperativas e em rede o Grupo Gestor cria justamente o campo fértil de interfaces para que novos conhecimentos aflorem, facilitando a cooperação na geração de conhecimento. Em sua pesquisa sobre os sistemas de conhecimento e inovação a partir da ação coletiva nos Assentamentos da Região Metropolitana de Porto Alegre, GUTIÉRREZ (2012) coloca que essas estruturas socialmente organizadas em rede para transmição e compartilhamento de conhecimentos podem ser considerados uma característica central da trajetória desses assentamentos.

\subsection{O Habitar}

Entendendo que o conhecimento acontece e se expressa não só nas tarefas de trabalho, mas no conjunto de relações sociais e ecológicas que envolvem cada agricultor, essa sessão se dedica a tratar dos processos que vão além do processo de produção e comercialização do arroz. Assim, acredita-se que o vínculo entre esta dimensão e o processo construção do conhecimento agroecológico é menos pragmático do que as anteriores, tendo um significado mais ontológico sobre a forma como os agricultores percebem seu estar no mundo e sua inserção com o ambiente. Diferente das seções anteriores onde o texto percorreu situações vividas ao longo do ciclo produtivo, os acontecimentos e percepções que aparecem nesta dimensão não seguem uma linearidade temporal, mas sim um continuum de ações, práticas e sensações que revelam formas de habitar o mundo. Portanto, a ilustração também se apresenta como um continuum entre as principais "áreas" presentes do Assentamento (áreas residenciais, áreas de proteção ambiental e áreas de lavoura) e como estas são percebidas no cotidiano através das relações familiares e comunitárias. Especial atenção é dada neste artigo, a dinâmica de convivência e percepção com o RVS Banhado dos Pachecos e seus habitantes, visto que sua 
consolidação foi o elemento central para a imposição do Estado para a produção agroecológica, bem como a origem de diversas outras restrições em relação já mencionadas na sessão 3. Também em muitas conversas prévias a pesquisa essa coexistência era vista como um ponto nevrálgico do Assentamento, sendo a localização e relação com as unidades de conservação referida como a principal problemática vivida no Assentamento ou vice-versa, o Assentamento visto como o maior problema para o RVS.

No entanto, surpreendentemente, ao se aproximar dos agricultores o RVS nunca foi citado como uma questão problemática, limitante ou um desafio a ser transposto, bem pelo contrário. A maneira como as famílias se expressam demonstra noções de afetividade, relevância, satisfação ou até mesmo orgulho. Esses simbolismos ficam evidentes na fala de Horácio ao comentar "Tu viu o Globo Repórter que passou outro dia? Foi aqui, eles não falam, mas é aqui! São os cervos daqui de dentro. Essa área é para preservar essa vida selvagem que nos temos aí dentro". Além disso, não há, por parte dos assentados, uma percepção clara de separação do RVS em relação ao restante do Assentamento. Ainda que se entenda que legalmente há uma área definida, na prática é vista como mais uma das áreas do assentamento como as lavouras e os setores de residência, que ainda que sejam demarcadas se entrelaçam. Portanto, são comuns os relatos de animais transitando entre as áreas, como contam Ana e Pedro.

Como é proibida a caça os bichos vão de amansando, daí os bichos vem
tudo aqui! Os passarinhos comem meus tomates, as folhas tudo [...]. As
capivaras gostam mesmo é de aipim! O bugio vem aqui do lado de casa.
Tu tens que ver, eu adoro isso! Tenho muita alegria com isso, as minhas
netas vêm, tiram foto. É muito bom isso porque as crianças convivem com
a natureza e aprendem a respeitar (Ana, agricultora assentada). Naquele valo ali, mora um jacaré e uma capivara. Não sei bem como eles se dão, mas moram aí e já faz anos! (Pedro, agricultor assentado).

Conforme relatado anteriormente, o processo de consolidação da APA do Banhado Grande aconteceu paralelamente à consolidação do Assentamento e a implementação do RVS Banhado dos Pachecos ocorreu quatro anos após os assentados já estarem ocupando a área em Viamão, sem que houvesse um processo de inclusão destas famílias na criação da UC. A negociação da área se deu de forma exclusiva entre a SEMA e o INCRA, como proprietário oficial das terras. Assim, desde a constituição das UC tem sido criado um cenário de tensão com o Assentamento. Entende-se que essa tensão tem suas raízes no modelo de gestão de recursos de uso comum e de preservação ambiental em vigor, onde as múltiplas realidades das comunidades locais são pouco consideradas. Nesse sentido, a produção de alimentos e a preservação de ecossistemas são vistos como questões antagônicas. Mais do que uma diferença de percepções ou opiniões, há diferentes formas de se relacionar com o ambiente e seus elementos e o que significa preservação. Essas divergências ficam claras quando se discute, por exemplo, a presença dos cachorros no Assentamento, conforme vamos nas falas de Manuel, o gerente da UC e um dos agricultores: 
Outro problema que eu vejo aqui e dos mais sérios é a entrada de cachorros domésticos. É seríssimo!. Aqui cada casinha, cada lote, tem 5-6, vai multiplicar isso para o entorno. Eles entram, eles percorrem as trilhas, caçam, tenho registro disso...então é um problema seríssimo, eles afastam os animais silvestres, deixam os bichos estressados, tem o risco de transmitir doenças, raiva, cinomose, são animais predadores. É um impacto muito, muito grande! (Manuel, gerente do RVS Banhado dos Pachecos)

Concordo que tem que preservar essa vida selvagem que tem aí dentro. Mas tenho um pouco de dificuldade de entender algumas coisas, algumas idéias! Por exemplo, se a gente fosse levar isso a risca eu não poderia ter a minha companheira de luta que me acompanha todo o dia aqui em baixo (cachorra) por que ela caça o rato, o ratão. Ele é selvagem, que nem o cervo! Mas é a natureza dela, ser assim! Umas coisas, podem, outras não podem, então é difícil entender essas coisas, até onde que é ruim, até onde que é bom? (Horácio, agricultor assentado).

Essa "confusão" sobre quais os animais importantes de serem preservados e os que deveriam ser excluídos e eliminados também é mencionado pelo gestor da UC ao mencionar que os assentados buscam ele para resolver problemas de roubo com seus animais. Mais do que uma confusão em relação ao papel dos agentes do Estado e o que é "ruim ou bom" para as Unidades de Conservação, há uma inconformidade com o tratamento que recebem do Estado em que devem ter uma conduta correta frente aos recursos e animais do RVS, sendo a obrigatoriedade da produção com certificação orgânica um exemplo. No entanto, essa exigência uma prerrogativa que não se estende aos vizinhos produtores de arroz que praticam uma agricultura convencional e altamente embasada em insumos químicos, as indústrias do entorno que também utilizam as mesmas fontes de água ou a própria população urbana que frequenta a Barragem.

Aqui no lado ainda tem isso ai, veneno! Pode ir aí no lado que te falam vários nomes de produto ali e tu vai lá conferir [...] eles dão 3-4 vôo ali e elimina tudo quanto é bicho! E tu acha que isso não vai chegar aqui também? (Nestor, agricultor assentado).

A gente trabalha pela vida, mas não ta sendo retribuído [...] A gente preserva tanto essas águas que é vida, é o que mantém a cidade lá para baixo, os outros vizinhos não respeitam entendeu? Eles pegam a água que nos largamos e põe veneno! E só nós é que somos cobrados, ta bem! Tem que ser cobrado para fazer direito, mas eu acharia que deviam também cobrar mais dos outros! (Alfredo, agricultor assentado)

Durante entrevistas o gestor manifestou que entende que o fato das famílias assentadas no entorno pertencerem a uma mesma comunidade (um Assentamento) torna mais fácil a sua atuação, o que seria mais difícil em caso de serem várias propriedades particulares realizando cultivo com uso de agrotóxicos. Ela também confirma que os problemas relatados pelos assentados existem e que realmente são provocados muito mais por pessoas de fora do Assentamento. Mas o mais relevante é notar que as distintas percepções vão além da função ao impacto dos animais domésticos ou determinadas práticas, mas carregam ao fundo uma 
visão de mundo sobre a natureza e o que significa ou o que mobiliza a preservação de determinadas áreas e espécies. Tais divergências não são exclusivas do Assentamento, mas estão no centro dos debates sobre a gestão de recursos de uso comum vem sendo feito há décadas a nível internacional. Conforme Berkes (2005) as abordagens referentes aos recursos seguem duas questões essenciais: (a) quem tem acesso ao recurso? (questão da exclusão) e (b) quais são as regras de uso do recurso? (questão da regulamentação). É com base nessas características que alguns recursos são ditos "recursos de uso comum", por serem recursos aos quais a exclusão ou o controle ao acesso por parte dos usuários é difícil e o uso compartilhado potencialmente permite que cada usuário subtraia o que também pertence a outros (BERKES, 2005). Uma teoria de destaque que busca explicar tal dilema é a "tragédia dos comuns" proposta por Hardin (1968), de forma sintética argumenta que o livre acesso a recursos finitos, somado a uma demanda crescente, levaria a uma superexploração inevitável em um contexto em que "a liberdade no uso de recursos comuns provoca a ruína de todos". Assim, a solução proposta pelo autor é de que para garantir um uso racional dos recursos estes deveriam ser privatizados ou mantidos pelo Estado, tendo regras de acesso e uso (HARDIN, 1968).

No caso Brasileiro, a própria legislação contém divergências basilares, visto que a Lei $n^{\circ}$ 9.985/2000 que rege o Sistema Nacional de Unidades de Conservação da Natureza - SNUC teve seu embasamento em uma abordagem preservacionista clássica, que vê a presença humana como uma ameaça à conservação, mas incorporou uma série de conceitos socioambientais que permitem uma perspectiva de interface entre biodiversidade e sociodiversidade, permeada pelo multiculturalismo e pela plurietnicidade (SANTILLI, 2005). Assim, entre as diretrizes que devem reger a gestão das $U \mathrm{C}^{8}$, consta que esta deve ser assegurada a participação efetiva das populações locais na criação, implantação e gestão das unidades de conservação, considerando as condições e necessidades destas populações no desenvolvimento e adaptação de métodos e técnicas de uso sustentável dos recursos naturais. $O$ instrumento proposto para efetivar a participação da sociedade e a democratização da gestão das UC se dá através da organização de Conselhos responsáveis pela gestão da área, bem como a elaboração, implementação do Plano de Manejo (SANTILLI, 2005).

No entanto, na prática a perspectiva preservacionista tem prevalecido e o processo de implementação das UC tem perpetuado uma concepção moderna de "meio ambiente" que conforme coloca Ingold (2000) ao invés de possibilitar nossa reconciliação com o mundo, assinala o ápice de um processo de separação entre humanidade e natureza. Assim, a implementação de UC raras vezes envolvem as comunidades residentes da área em questão, levando a situações de conflito onde o modo de vida da população local se contrapõe aos objetivos das UC (DIEGUES, 1994). As disputas tão recorrentes no país em torno de áreas protegidas e populações fazem com que os moradores locais, após terem suas áreas de residência ou entorno declaradas UC e sendo submetidas a regras impostas a nova condição, torna as pessoas criminosos por existirem, tornando-se um "problema" a ser resolvido.

\footnotetext{
${ }^{8}$ Art. $5^{\circ}$ do SNUC (BRASIL, lei n 9.985, de 18 de julho de 2000 ).
} 
Infelizmente, esse parece ser o contexto vivido no Assentamento, onde a tensão existente é entre o modelo de preservação imposto pelo Estado, e não com os ecossistemas como ambiente de entorno tampouco com a necessidade de preservação destes. As falas das famílias revelam isso, demonstrando que o conflito está relacionado com a visão dicotômica da relação entre sociedade e natureza do modelo em vigor, que mantém uma concepção estética e mitificada do mundo natural onde a única forma de mantê-lo estável e intocado seria o afastamento do convívio humano (DIEGUES, 1994). Sevilla Guzmán (2002) destaca que é justamente a essa perspectiva que ignora os sujeitos sociais vinculados ao manejo dos recursos naturais que a Agroecologia se coloca de forma crítica, pois é uma consequência do processo de cientificação aos quais os recursos têm sido submetidos constituindo um "modo industrial de uso dos recursos naturais" que continuamente só tem contribuído para a degradação ambiental e social. Ou ainda como colocaria Ingold (2000), uma visão Ocidental moderna desengajada do ambiente, onde a agricultura e o cultivo de alimentos seriam uma ação humana de imposição a uma natureza subordinada, reproduzindo uma crença de que o homem e suas práticas não pertencem aos ecossistemas, e por isso devem ser afastados.

É a essa relação distanciada que as famílias expressam quando falam da equipe de funcionários que atuam no RVS, referenciados como o "Meio Ambiente" personificado, como agente de controle e fiscalização, e que em nada revela a relação dos assentados com o ambiente de entorno.

O "Meio Ambiente" protege pouco isso ai, mas o "Meio Ambiente" meio que tinha que cuidar direto disso! Vem gente diferente aqui na lavoura, vem esses carros de fora pescar...A gente não sabe quem é e nem pode falar. Eles tinham que cuidar mais um pouquinho disso ai, se eles não querem que venha gente de fora para cá então devia ser melhor a fiscalização. Eles falam que muita coisa que foi feita que é tudo dos assentado, mas não é! É coisa de gente de fora! (Nestor, agricultor assentado)

Não gosto desses pescadores de fora que entram ai! Eles matam os bichos, matam gado, fazem churrascada, deixam muito lixo espalhado, é uma porcalhada [...]. O pessoal do "Meio Ambiente" fiscaliza, mas é complicado! Eu achava que tinha ser até um pouco mais rígido. $O$ nosso povo não caça, não pesca, isso é o pessoal de fora (Ernesto, agricultor assentado).

Vem bastante gente de fora aí, pescar, roubar, incomodar [...]. As minha pá sempre roubam, acho que vão pegar minhoca e jogam no valo! E tudo que fica no barraco, já me roubaram muita coisa! Nossos guarda florestal acho que foram tudo demitido, porque não aparecem mais [...] É ruim porque isso (o refúgio) ajuda o assentamento, isso ajuda o meio ambiente e isso vem a ajudar a todos nos! Não só o assentamento, mas também os de fora! Mas to achando que os de fora não tão tendo o reconhecimento que o Assentamento deveria ter, entendeu? Pela grande ajuda que ele dá para cidade, que é essa água ai que eles bebem, a qualidade dela é pelo nosso jeito de trabalhar (Alfredo, agricultor assentado).

Além de exemplificaram uma visão mais integral sobre a interconexão sócio ecológica do ambiente em que vivem, as falas de certa forma também validam as palavras de Diegues (1994) ao afirmar que essa perspectiva dicotômica demonstra- 
se extremamente antropocêntrica e beneficia, em especial, as populações urbanas que residem longe do ambiente natural e precisam de um espaço de recreação para amenizar as pressões ecológicas que vivem nas cidades. Assim, o autor esclarece como a concepção de "mundo natural" é distinta entre as populações urbanas e de povos indígenas ou rurais por dependerem do meio para sua reprodução, estabelecendo relações mais integradoras onde o natural passa a ser parte se seu modo de vida (DIEGUES, 1994).

Um último elemento que não podemos deixar de mencionar se refere ao conhecimento sobre a existência dos cervos, tidos como algo precioso a RVS. A existência dos remanescentes da espécie era comentados pelos agricultores assentados dede que chegaram, no entanto, o Estado e até mesmo a comunidade acadêmica não consideram isso como um fato até a chegada do Gestor, como o mesmo conta:

\begin{abstract}
O cervo é uma espécie que é bandeira, por ser um símbolo dos banhados da região, da bacia do Gravataí. É uma espécie "guarda-chuva", é um animal que tu conseguindo conservar essa espécie tu consegue conservar todas aquelas outras espécies associadas as áreas de Banhado e a vegetação inclusive. Então é fundamental, é o símbolo da região. E até então mal sabia se ele ainda existia aqui na região quando eu entrei. Ele renasceu no momento que eu disse "o bicho ta lá ainda". Os assentados falavam e tal, viam [...]. Mas ninguém, nenhum dos pesquisadores acreditava, na FZB ninguém acreditava que ele tava vivo ainda aqui, eles diziam esta extinto já. Daí quando eu entrei, primeiro eu vi por rastros, pegadas e daí pensei "não ele deve tá La!" Trouxe câmeras, registros fotográficos, hoje agora nos temos 140 registros fotográficos de cervo e mais e quase uma hora de filme, tem um monte de informação (Manuel, gerente do RVS Banhado dos Pachecos, grifos as autora)
\end{abstract}

Ainda que talvez sem perceber o peso da própria fala, o que o gestor afirma no que trecho citado é que o conhecimento dos agricultores que já viviam no local e conviviam com os cervos no seu cotidiano, era desconsiderado como válido tanto pelo Estado como pela Academia. A existência dos cervos só passa a ser considerada real, após a alegação de um ator externo com formação científica, o gestor, presenciar os vestígios do animal. Importante destacar que vemos nessa visão, não uma perspectiva pessoal, mas a reprodução do pensamento acadêmico científico e na forma fragmentada em como o conhecimento tem sido reproduzido nas sociedades. Assim, nas formações de ciências naturais se aborda em exaustão os fenômenos físicos, químicos, matemáticos, se desseca e analisa todas as formas de vida, porém pouco ou nada se aprende sobre como humanos e não-humanos interagem. É a desvalorização do conhecimento endógeno em relação ao científico. Ou seja, aquilo que é vivido, visto e dito pelas famílias a partir de seu engajamento com o ambiente não é digno de consideração. Interessante que a própria ciência acaba por demonstrar que a lógica separatista acadêmica, na prática não se mantém. Ao realizar uma pesquisa sobre a diversidade de insetos predadores no Assentamento, comparando áreas de cultivo de arroz com áreas do RVS, Ferreira (2012) observou que há espécies de predadores compartilhadas entre as duas áreas, o que indica que a área de reserva legal pode atuar como repositório de inimigos naturais para as áreas cultivadas. Assim, a ineficácia das cercas que impõe os limites territoriais do RVS somado aos relatos de presença de bugios, jacarés, capivaras e cervos em áreas de lavoura, horta e pátio das casas, ao fim, revelam a inconsistência 
e impossibilidade de se pensar na preservação destas espécies como contidas em uma ilha de preservação. Revelam, portanto a demonstram a fragilidade da lógica preservacionista de ilhas de contenção.

Quando questionado sobre a possibilidade dos Assentados auxiliarem na gestão da UC, o gestor ainda que entenda que a falta de um conhecimento sistemático e equipamentos adequados inviabilizaria essa dinâmica, ainda que reconheça que a interação cotidiana das famílias com a área e seus elementos fornece dados sobre a existência, localização e hábitos dos animais. O histórico do processo de implementação do Assentamento, complementados pelos relatos das famílias fica evidente que estas famílias são vistas pelo Estado como uma ameaça permanente a integridade e concretização dos objetivos das UC, colocando os assentados em situação de marginalização e confronto. Essa postura ignora a possibilidade das famílias como cogestores das UC, onde através de seu conhecimento e sua forma de habitar poderiam na verdade auxiliar e potencializar as condições para a existência e reprodução de espécies da flora e da fauna local.

\section{Considerações Finais}

Este artigo teve como objetivo apresentar e discutir as dimensões do conhecimento agroecológico vivenciado pelos agricultores familiares vinculados ao Assentamento Filhos de Sepé. A agroecologia tem sido debatida na literatura internacional como a principal referência para a criação de sistema agroalimentares sustentáveis, fazendo com que sua ampliação e disseminação seja quizá um imperativo frente à necessidade de abastecer a população com alimentos seguros e saudáveis de forma paralela a mitigação das desigualdades sociais e das mudanças climáticas. Assim, conhecer os processos e saberes gerados na busca por soluções localizadas se tornam elementos importantes no processo de transição e construção do conhecimento agroecológico.

O processo desenvolvido pelos agricultores familiares do Assentamento Filhos de Sepé envolve três dimensões - a lavoura, o corre e o habitar. Essas dimensões foram identificadas a partir de uma pesquisa qualitativa que buscou compreender a perspectiva dos atores protagonistas do processo e considera tanto os aspectos relacionados à produção do arroz agroecológico per se, como também as dinâmicas socioeconômicas que envolvem a logística de plantio, processamento e comercialização do grão e a esfera sócio-ecológica que informa sobre a visão de mundo e vida que os agricultores portam. Assim, as dimensões se interpõem e entrelaçam no cotidiano vivido pelos assentados, criando uma série de interfaces e contribuindo para que possam realizar suas atividades produtivas e reprodutivas. $O$ resultado é a emergência de um conhecimento complexo, multidisciplinar e heterogêneo que emerge a partir da prática e do engajamento dos agricultores com o mundo, rompendo com dicotomias clássicas sobre a relação sociedade-natureza e a agricultura receituária. O contexto agrícola atual requer agricultores familiares multifacetados, em que as habilidades de manejo de cultivos são apenas uma entre as funções desempenhadas, fazendo com que diferentes aprendizados (administração, gestão, contabilidade, etc..) precisem ser desenvolvidos. A troca de saberes é altamente relevante, seja entre seus pares, seja entre técnicos, 
As dimensões do conhecimento agroecológico: a experiência dos agricultores familiares assentados em Viamão, RS

pesquisadores ou ainda os elementos naturais com quem interagem cotidianamente.

Acredita-se que pelo menos três contribuições do artigo merecem destaque. A primeira é o referencial teórico utilizado que tem o potencial de contribuir com os estudos sobre o conhecimento agroecológico. Ainda que o termo "conhecimento agroecológico" seja de amplo uso, poucos estudos têm se dedicado a pensar como este conhecimento se processa em termos corporais e mentais ou ainda como se insere no extenso debate sociológico sobre construção do conhecimento. Em especial, salienta-se que a antropologia ecológica proposta por Ingold traz um arcabouço teórico consistente e coerente com a Agroecologia enquanto ciência e prática social, dando densidade ao processo de construção do conhecimento e uma solução elegante a dicotomia sociedade e natureza criticada por ambas, porém, pouco aprofundada no campo agroecológico.

Em segundo lugar, a metodologia de pesquisa com o uso de construção coletiva de ilustrações pode auxiliar a inspirar outros estudos que visam sistematizar conhecimentos desenvolvidos a partir da prática e vivência dos agricultores. Aqui ressalta-se que a potencial inovação frente a outras metodologia que envolvem o uso de recursos visuais, está na dinâmica de repetição da elaboração dos desenhos com as famílias e a discussão interativa com os diferentes atores, provocando processos de reflexão sobre as distintas formas de saber, levando a constante re-elaboração das ilustrações. Por fim, acredita-se que a trajetória e os dilemas enfrentados pelos agricultores assentados em Viamão trazem elementos relevantes para se pensar a relação do Estado frente a reforma agrária, a transição agroecológica e a gestão de áreas de interesse ambiental em conjunto com populações locais. De uma perspectiva mais acadêmica, mais do que respostas, espera-se ter elencado reflexões que possam inspirar novos estudos sobre o processo de construção do conhecimento agroecológico e o protagonismo dos agricultores na criação de sistemas agroalimentares sustentáveis.

\section{REFERÊNCIAS}

ASSOCIAÇÃO BRASILEIRA DE AGROECOLOGIA - ABA. Construção do Conhecimento Agroecológico. Brasília: ABA, 2007.

BASSI, J.B.; COELHO DE SOUZA, G.\& KUBO, R.R. Etnoecologia contemporânea e interdisciplinaridade: contribuições da antropologia ecológica de Tim Ingold. In: Anais do IV Encontro da Rede de Estudos Rurais: Mundo rural, políticas públicas, instituições e atores em reconhecimento político. Curitiba/PR: UFPR, 2010.

BERKES, F. "Sistemas Sociais, Sistemas Ecológicos e Direitos de Apropriação de Recursos Naturais”. In VIEIRA, P.F.; BERKES, F.; SEIXAS, C.S. Gestão Integrada e Participativa de Recursos Naturais: Conceitos, Métodos e Experiências. Florianópolis: Secco/APED, 2005. 
BRACAGIOLI, A. Desenvolvimento e envolvimento da agricultura no sul do Brasil: abordagem crítica do processo de desenvolvimento. Encontro Nacional de Agroecologia. Anais. Rio de Janeiro: AS-PTA, 2003. p. 33-35

CANUTO, J.C. Reflexões sobre o estado da arte do conhecimento agroecológico. In: SEMINÁRIO INTERNACIONAL SOBRE AGROECOLOGIA, 9., 2008, Porto Alegre.

Palestra. Porto Alegre: Aba, 2008. p. 1 - 9. Disponível em:

<http://www.cisguanabara.unicamp.br/redeAgroecologia/arquivos/biblAgroecologia /reflexoesestadodaarte.pdf >. Acesso em: 2 fev. 2013.

CANUTO, João Carlos. Agroecologia: princípios e estratégias para o desenho de agroecossistemas sustentáveis. Redes (Santa Cruz do Sul. Online), Santa Cruz do Sul, v. 22, n. 2, p. 137-151, abr. 2017. Disponível em:

<https://online.unisc.br/seer/index.php/redes/article/view/9351>. Acesso em: 28 nov. 2019 .

CARMO, M.S. COMITRE, V.; FAGUNDES, G. TERMO DE REFERÊNCIA:

AGROECOLOGIA E TRANSIÇÃO AGROECOLÓGICA. Campinas: Rede de Agroecologia da Unicamp, 2012.13 p. Disponível em:

<http://www.cisguanabara.unicamp.br/redeAgroecologia/arquivos/biblAgroecologia /termodereferencia.pdf>. Acesso em: 29 out. 2012.

CARON, P. et al. Food systems for sustainable development: proposals for a profound four-part transformation. Agronomy for Sustainable Development, v. 38, n. 41, p. 1-12, Aug. 2018.

COTRIM, D.S.; DAL SOGLIO, F.K.. Construção do Conhecimento Agroecológico: Problematizando a noção. Revista Brasileira de Agroecologia, v. 11, n. 3, Sep. 2016. Disponível em: <http://revistas.aba-

agroecologia.org.br/index.php/rbagroecologia/article/view/16772>. Acesso em: 28 nov. 2019.

DIEL, R. Gestão racional de recursos naturais de uso comum: recursos hídricos em produção de arroz irrigado no assentamento Filhos de Sepé - Viamão/RS. 2011. 84 f. Dissertação (Mestre) - Curso do Programa de Pós-graduação em Agroecossistemas, Departamento do Centro de Ciências Agrárias, Universidade Federal de Santa Catarina, Florianópolis, 2011.

DIEGUES, Antônio Carlos. O mito moderno da natureza intocada. São Paulo: NUPAUB - Universidade de São Paulo, 1994.

GLIESSMAN, S. R. Agroecologia: processos ecológicos em agricultura sustentável. 4. ed. Porto Alegre: Editora da UFRGS, 2009.

GUTIÉRREZ, L.A.L. agroecologia e desenvolvimento de assentamentos de reforma agrária: ação coletiva e sistemas locais de conhecimento e inovação na Região Metropolitana de Porto Alegre. 2012. 407 f. Tese (Doutorado) - Curso de Ciências 
As dimensões do conhecimento agroecológico: a experiência dos agricultores familiares assentados em Viamão, RS

Humanas, Departamento decentro de Filosofia e Ciências Humanas, Universidade Federal de Santa Catarina, Florianópolis, 2012.

HARDIN, Garrett. The Tragedy of the Commons. Science, 162: 1243-1248, 1968.

HEIDEGGER, M. Ser e tempo. Petrópolis - RJ: Vozes, 2000.

HIGH LEVEL PANEL OF EXPERTS ON FOOD SECURITY AND NUTRITION OF THE COMMITTEE ON WORLD FOOD SECURITY - HLPE Agroecological and other innovative approaches for sustainable agriculture and food systems that enhance food security and nutrition. Rome: HPE, 2019.

INFINDHA. Plano de Consolidação do Projeto de Assentamento Viamão. Porto Alegre, 2004.

INGOLD, T. The Perception of the Environment: Essays in Livelihood, Dwelling and Skill. London: Routledge, 2000.

INSTITUTO DE PESQUISA ECONÔMICA APLICADA - IPEA. Relatório da II Pesquisa Nacional sobre a Educação na Reforma Agrária. Brasília: IPEA, 2015.

INTERNATIONAL PANEL OF EXPERTS ON SUSTAINABLE FOOD SYSTEMS - IPESFood. From uniformity to diversity: a paradigm shift from industrial agriculture to diversifed agroecological systems. Brussels: IPES-Food, 2016.

MERLEAU-PONTY, M. Fenomenologia da percepção. São Paulo: Martins Fontes, 1999.

MOLINA, M.G. Introduccion a la Agroecologia. Madrid: Sociedade Española de Agricultura Ecológica (SEAE), 2011.

NÓBREGA, T. P. Corpo, percepção e conhecimento em Merleau-Ponty. Estud. psicol., Natal, v. 13, n. 2, p. 141-148, Ago. 2008.

NOGAARD, R.B.. The Episteomology Basis of Agroecology. In: MIGUEL, Altieri. Agroecology: The Scientific Basis of Alternative Agriculture. Boulder: Westview Press, 1987.

PARANHOS, M.G. F.; SILVEIRA, L.M.; NOGUEIRA, F. A trajetória da Rede Ater Nordeste: construindo conhecimento agroecológico pelo Nordeste brasileiro. Construção do Conhecimento Agroecológico: Novos Papéis, Novas Identidades, Brasília, n. , p.58-70, jul. 2007.

PETERSEN, P. et al. A construção de uma ciência a serviço do campesinato. In: PETERSEN, P.; In: Construção do Conhecimento Agroecológico: Novos Papéis, Novas Identidades, Brasília: Articulação Nacional da Agroecologia, 2007. 
PETERSEN, P. Agricultura familiar camponesa na construção do futuro. Rio de Janeiro: AS-PTA, 2009.

PLOEG, J.D.. Sete teses sobre a agricultura camponesa. In: PETERSEN, P. Agricultura Familiar Camponesa Na Construção do Futuro, Rio de Janeiro: AS-PTA, 2009.

POLANYI, M. The tacit dimension. Garden City, NY, 1966.

PRIMAVESI, A. Agroecologia e manejo do solo. Agriculturas , v. 5; n. 3; set. 2008.

SABOURIN, E. Sociedades e organizações camponesas: uma leitura através da reciprocidade. Porto Alegre: UFRGS, 2011.

SANTILLI, Juliana. SOCIOAMBIENTALISMO E NOVOS DIREITOS:proteção jurídica à diversidade biológica e cultural. São Paulo: Peirópolis, 2005.

SEMA. Comitê de Gerenciamento da Bacia Hidrográfica do Rio Gravataí. Comitês De Gerenciamento De Bacia Hidrográfica, Porto Alegre, 27 set.. 2012. Disponível em: <http://www.sema.rs.gov.br/conteudo.asp?cod_menu=295>. Acesso em: $21 \mathrm{dez}$. 2012.

SEVILLA-GUZMÁN, E. A perspectiva sociológica em Agroecologia: uma sistematização de seus métodos e técnicas. Agroecologia e Desenvolvimento Rural Sustentável, Porto Alegre, v. 3, n. 1, p.18-28, mar. 2002.

WEITZMAN, R. Construção participativa de um modelo de formação de educadores(as) comunitários(as) em segurança alimentar e nutricional e agricultura urbana. PETERSEN, P.; (org.) In: Construção do Conhecimento Agroecológico: Novos Papéis, Novas Identidades, Brasília: Articulação Nacional da Agroecologia. , p.196-217, jul. 2007.

WEZEL, A., BELLON, S., DORÉ, T. ; FRANCIS, C.; VALLOD, D.; DAVID, C. Agroecology as a science, a movement and a practice: a review. Agronomy for Sustainable Development. , v. 29, n. 503, p. 2-13, Dec. 2009.

Potira V. Preiss. Dra. em Desenvolvimento Rural, pesquisadora Pós-Doc no Programa de Pós-Graduação e Desenvolvimento Regional da Universidade de Santa Cruz do Sul - PPGDR/UNISC, através do Programa Nacional de PósDoutorado PNPD/CAPES.potira@unisc.br

Como citar: PREISS, Potira Viegas. As dimensões do conhecimento agroecológico: a experiência dos agricultores familiares assentados em Viamão, RS. Redes (St. Cruz Sul, Online), Santa Cruz do Sul, v. 25, n. 1, jan. 2020. ISSN 1982-6745.

DOI: https://doi.org/10.17058/redes.v25i1.14685. 